\title{
Why and how does shared language affect subsidiary knowledge inflows? A social identity perspective
}

\author{
B. Sebastian Reiche ${ }^{1}$, \\ Anne-Wil Harzing ${ }^{2}$ and \\ Markus Pudelko ${ }^{3}$ \\ ${ }^{1}$ Department of Managing People in \\ Organizations, IESE Business School, Barcelona, \\ Spain; ${ }^{2}$ Middlesex University Business School, \\ London, UK; ${ }^{3}$ Department of International \\ Business, Tübingen University, Tübingen, \\ Germany
}

Correspondence: BS Reiche, Department of Managing People in Organizations, IESE Business School, Ave. Pearson, 21, Barcelona 08034, Spain.

Tel: +34 936024491 ;

email: sreiche@iese.edu

\begin{abstract}
Extending existing international business (IB) research, we conceptualize shared social identity as an outcome rather than only an antecedent of multinational enterprise knowledge flows to provide an alternative reason for why such knowledge flows occur. We further argue that shared language among subsidiary and headquarters (HQ) managers is an insufficient condition for subsidiary knowledge receipt. Accordingly, we develop a moderated mediation model at the subsidiary level to examine how shared language affects subsidiaries' tacit knowledge inflows from HQ. Specifically, we study (1) whether this relationship is mediated by the extent to which subsidiary managers share $\mathrm{HQ}$ goals and vision, and the extent to which Human Resources decisions are centralized at $\mathrm{HQ}$; and (2) whether subsidiary type (greenfields vs acquisitions) moderates these mediated relationships such that in both cases the mediation will be stronger in foreign acquisitions compared with foreign greenfields. Building on a sample of 817 subsidiaries in 9 countries/regions and a novel subjective measure of shared language, we find support for our model. Implications for research on HQ-subsidiary knowledge flows, social identity theory and the literature on sociolinguistics, and international Human Resource Management are discussed and managerial implications outlined.
\end{abstract}

Journal of International Business Studies (2015), I-24. doi: 10.1057/jibs.2015.3

Keywords: MNE knowledge flows; social identity theory; sociolinguistics;

shared language; headquarters-subsidiary relations; human resource management

The online version of this article is available Open Access

\section{INTRODUCTION}

Over the past decades, multinational enterprises (MNEs) have increased their exposure to foreign markets, both in terms of the number of countries they operate in and the scope of activities they perform abroad. This has resulted in increased levels of globally distributed work and cross-national collaboration (Hinds, Liu, \& Lyon, 2011) whose effectiveness is contingent on the exchange of locally imprinted knowledge from one context to another (Bhagat, Kedia, Harveston, \& Triandis, 2002). Because a large part of the knowledge in MNE units is contextual and tacit in nature (Gupta \& Govindarajan, 2000), the transfer of knowledge depends on actors adequately conveying and making sense of its meaning (Argote \& Ingram, 2000).
Received: 25 October 2013

Revised: 9 January 2015

Accepted: 15 January 2015

Online publication date: 2 April 2015 
Recently, scholars have therefore started to point to the role of shared language for tacit knowledge flows in MNEs (e.g., Mäkelä, Kalla, \& Piekkari, 2007; Peltokorpi \& Vaara, 2014). In MNEs, different units may share a language either because their members are proficient in the native language that is spoken in the respective other unit, or they may share a common corporate language that the organization has defined (Marschan-Piekkari, Welch, \& Welch, 1999a). Indeed, an increasing number of MNEs have started to implement shared language policies, usually in the form of a mandate for English as a common corporate language, leading to significant improvements in communication, coordination and control, and in turn performance (Harzing \& Pudelko, 2014; Neeley, 2012). However, given the many challenges that MNEs face as multilingual entities (Luo \& Shenkar, 2006), surprisingly little research has systematically examined the link between shared language and MNE knowledge flows.

While shared language and knowledge exchange, and tacit knowledge exchange in particular (Argote \& Ingram, 2000), are inherently relational concepts, existing theoretical approaches have tended to study the characteristics of the exchange actors and those of the knowledge itself as the focal determinants of MNE knowledge flows (e.g., Fang, Jiang, Makino, \& Beamish, 2010; Simonin, 2004; Yang, Mudambi, \& Meyer, 2008). Research integrating these determinants with the relevant shared properties between the exchange actors (such as language) or the underlying transfer mechanisms (such as organizational practices) has however been scarcer (Michailova \& Mustaffa, 2012; Song, 2014). In addition to shared structural elements such as social ties, scholars have highlighted the importance of relational elements that include shared trust and identity (Nahapiet \& Ghoshal, 1998). Social identity theory (Tajfel \& Turner, 1986; Turner, 1982) provides a theoretical rationale for studying the link between shared language and MNE knowledge flows because (1) it offers an alternative reason for why tacit knowledge exchange may occur between particular sets of actors and (2) it helps explain how, that is, through which mechanisms actors' language characteristics in relation to those of their counterparts translate into knowledge flows.

Specifically, we conceptualize the transfer of tacit knowledge as an act to construct a shared identity because it provides the deep contextual understanding that allows individuals to do so (Ashforth, Harrison, \& Corley, 2008; Bucholtz \& Hall, 2005; Ochs, 1993). This is particularly important in MNEs where individuals are dispersed across units with distinct social identities (Reade, 2003; Vora \& Kostova, 2007). To focus on one specific social group within MNEs, we follow Kostova and Roth (2002) in considering the MNE subsidiary as the main knowledge recipient and study how shared language among subsidiary and headquarters (HQ) managers, operationalized at the aggregate subsidiary level, affects subsidiary knowledge inflows from HQ as an act to develop a shared HQ identity. Given the relevance of tacit knowledge for constructing a common identity, we focus on procedural knowledge such as R\&D or distribution know-how rather than more operational information.

While social identity theory suggests several sources that can act as markers for social identification, including gender, ethnicity, race and culture (Tajfel \& Turner, 1986; Turner, 1982), in this study we focus on language as one particular determinant. Language is possibly an even more important determinant for social identification than other attributes as it is an acquired characteristic that sets clear functional and psychological barriers to social interaction (Giles \& Johnson, 1981). Although scholars of sociolinguistics and the social psychology of language have long recognized the role of language in this respect, it is less clear how exactly shared language translates into a social identity (Lauring, 2008; Ochs, 1993) and hence into knowledge transfer as an act to construct a shared identity. We propose that subsidiary managers sharing a language with HQ managers will be able to properly understand knowledge from HQ and apply it to construct a common social identity with $\mathrm{HQ}$ if they share the HQ goals and vision (Brannen, 2004; Orton \& Weick, 1990). Further, they will be motivated to acquire HQ knowledge to construct a common social identity if the MNE makes HQ identification more rewarding by centralizing Human Resources (HR) decisions (Ellemers, de Gilder, \& Haslam, 2004; Pratt, 1998). Finally, compared with foreign greenfields we expect the ability- and motivation-related mediators to be more salient in foreign acquisitions because managers in these units will have less previous knowledge of and feel less socially integrated with HQ (Gupta \& Govindarajan, 2000; Stahl \& Voigt, 2008).

Our study draws on a large-scale sample of 817 subsidiaries in 9 different countries/regions that are headquartered in 36 different countries to make four contributions. First, we open the black box of the relationship between shared language and subsidiary inflows of tacit knowledge. While scholars have highlighted the role of shared language for MNE knowledge flows (e.g., Mäkelä et al., 2007; Nahapiet 
\& Ghoshal, 1998; Slangen, 2011), little research has provided (1) empirical support for the proposed positive relationship, or (2) theoretical arguments for how exactly shared language would affect MNE knowledge flows. Our study delivers empirical evidence for the assumed positive relationship by conceptualizing a moderated mediation model to tease apart the theoretical mechanisms through which shared language among subsidiary and HQ managers affects subsidiary knowledge inflows. By drawing on social identity theory and the literature on sociolinguistics, we also expand the theoretical bases underlying research on MNE knowledge flows (Michailova \& Mustaffa, 2012). Second, we develop a new subjective measure of shared language between subsidiary and HQ managers, which reflects the aggregate language commonalities perceived at the subsidiary level. Our measure of shared language is not limited to one specific language and addresses several limitations of objective country-level measures currently available (e.g., Dow \& Karunaratna, 2006). While existing measures may be appropriate for country-level studies, our findings challenge their use for examining subsidiary-level knowledge flows.

Third, we contribute to social identity theory and the literature on sociolinguistics by examining how shared language affects shared identity. The link between language and social identity has been characterized as "sociolinguistically distant" (Ochs, 1993: 288), suggesting mediation by other variables. We conceptualize both ability- and motivationrelated mediators of the relation between shared language and tacit knowledge receipt for constructing a common identity and, in doing so, also address calls for studying in more detail how social identification occurs (Ashforth et al., 2008). Fourth, we contribute to the international human resource management (HRM) literature by explaining when centralized HR decision making is beneficial for MNE knowledge transfer. While HRM is considered the most localized of functions, there is evidence for country-of-origin and dominance effects (Edwards \& Kuruvilla, 2005; Pudelko \& Harzing, 2007). Our findings suggest that MNEs not only centralize HR decisions to leverage home country approaches or converge to universal best practices, but also to motivate subsidiary managers to receive knowledge and construct a shared HQ identity.

\section{THEORETICAL BACKGROUND}

Social identity theory (Tajfel \& Turner, 1986; Turner, 1982) holds that any individual's self-concept is based not only on his or her personal identity but also on his or her group identity. Group identity can be derived from a large variety of social categories based on groups that individuals classify themselves into (e.g., gender, profession, ethnicity). Tajfel and Turner (1986) indicate that even trivial, ad hoc intergroup categorization can lead to in-group favoritism and discrimination against the out-group. When social identities are salient, stereotypes develop, relations between groups become competitive and mistakes or violations of social rules by members of another group are met with less tolerance (Hogg \& Terry, 2000). Strong attachment to the in-group, combined with current conflicts and/or a history of conflicts between the groups, will intensify these effects.

Although social identity theory is well established in social psychology, scholars have only begun to apply it to the MNE context. A first stream of research has adopted an individual level of analysis to examine the antecedents and consequences of the identities that subsidiary managers hold vis-à-vis the local subsidiary and the wider MNE (Reade, 2003; Vora \& Kostova, 2007). At the team level, studies have focused on the factors that explain the salience of identity-based sources of categorization and their implications for intra-group cooperation (e.g., Hinds \& Mortensen, 2005; Salk \& Brannen, 2000). At the organizational level, social identity-based mechanisms for inter-unit interaction and cooperation in MNEs have mainly been investigated in the form of cognitive social capital that concerns the extent to which actors share values, codes, norms and goals with one another (Reiche, Harzing, \& Kraimer, 2009; Tsai \& Ghoshal, 1998). Some scholars have pointed to potentially negative implications of having a shared social identity, including resistance to organizational change (Bouchikhi \& Kimberly, 2003). However, common to the above research streams are a number of benefits resulting from a shared social identity among actors both within and between MNE units, especially with regard to the exchange of knowledge.

While the limited international business (IB) literature has examined a common social identity as an antecedent to knowledge flows (e.g., Björkman, Stahl, \& Vaara, 2007; Hinds \& Mortensen, 2005), social identity scholars have also pointed to common knowledge as a prerequisite for developing a shared identity. For example, providing organizational members with firm-specific knowledge serves as a form of sensegiving to facilitate social identification (for a review, see Ashforth et al., 2008). Similarly, subsidiaries' acquisition of HQ knowledge will 
make them more similar to $\mathrm{HQ}$, fostering a common identity (Kostova \& Roth, 2002). The knowledge required for social identification is strongly rooted in interaction with other group members (Bucholtz \& Hall, 2005), and involves an understanding of and commitment toward often unconscious conventions in the social group (Ochs, 1993). Because such knowledge is difficult to codify and mainly built from experience, it is tacit in nature (Argote \& Ingram, 2000). Drawing on these arguments, we conceptualize subsidiary receipt of tacit knowledge as an act to construct a common identity with HQ.

MNE knowledge flows may occur in multiple directions, vertically between the HQ and a subsidiary, and horizontally between different subsidiaries (Noorderhaven \& Harzing, 2009; Yang et al., 2008). However, while subsidiaries' contributory roles depend on a specific set of subsidiary resources or the overall MNE strategy (e.g., Birkinshaw, Hood, \& Jonsson, 1998), virtually all subsidiaries receive knowledge from HQ. Our interest lies in disentangling the specific mechanisms that explain how shared language affects subsidiary knowledge inflows. Therefore rather than comparing conventional top-down and reverse bottom-up knowledge flows or investigating the possibility of lateral flows, we focus on tacit knowledge that flows from HQ to subsidiaries. Further, implicit to our arguments is that MNE knowledge flows have positive performance implications. However, given that the relation between subsidiary knowledge inflows and subsidiary performance has already been established (e.g., Chang, Gong, \& Peng, 2012; Fang et al., 2010), our aim rather is to examine shared language-related predictors of tacit knowledge receipt in subsidiaries.

Shared language should facilitate the development of a common social identity between HQ and subsidiary managers. Various interpersonal and intergroup determinants affect, and may interact in affecting the development of a shared identity (Tajfel \& Turner, 1979), including the degree to which the HQ and subsidiary national cultures differ (e.g., Björkman et al., 2007) or shared racial or ethnic background (e.g., Mehra, Kilduff, \& Brass, 1998). We realize that a specific focus on shared language, as any specific focus on a particular determinant, provides a limited perspective on social identity, a concept that is so complex that it can only be fully understood when considering the interplay of all determinants together. Our decision to focus on shared language is motivated by both conceptual and methodological reasons. Conceptually, language should be a more salient source of social identity than, for example, national culture or ethnicity because it sets stronger functional and psychological barriers to social interaction (Giles \& Johnson, 1981). Indeed, without language commonalities it is difficult if not impossible to interact and share knowledge, and hence construct a social identity, regardless of how close the respective cultures or ethnicities are. Further, especially in MNEs whose workforce is diverse and internationally mobile (Hinds et al., 2011), the national culture or ethnic composition of a country in which individuals are based (i.e., HQ or subsidiary countries) might be relatively less important as a source of their social identity. In particular, a large part of MNEs' worldwide $\mathrm{HQ}$-subsidiary interactions take place within the ethnically rather homogeneous Western world. By contrast, language is an acquired attribute whose acquisition intentionally facilitates interaction.

Given the methodological problems with objective measures of distance, particularly regarding culture, scholars have called for subjective assessments (e.g., Shenkar, 2001), which would also favor a linguistic focus. Specifically, it is more reasonable to ask subsidiary informants to assess HQ managers' linguistic capabilities, as this is something they experience directly and explicitly in their communication with HQ managers, than asking subsidiary managers to subjectively assess HQ managers' cultural capabilities or, given the prevalence of virtual communication in the MNE context, their ethnic background.

Despite these arguments, scholars have highlighted that the relation between shared language and social identity is far from deterministic. For example, poststructuralist conceptions view social identity as a site of struggle that is diverse and potentially contradictory, a notion that is especially relevant in the case of second language learning and use (Peirce, 1995). Similarly, rather than being explicitly encoded by language, social identity entails social meaning that is inferred based on a person's understanding and interpretation of linguistic constructions (Ochs, 1993). Scholars have also argued that language can be used strategically in identity formation (Lauring, 2008). Common to these arguments is that the link between shared language and social identity is not direct but mediated by more immediate constructs.

Specifically, although a shared language may trigger a process of identity construction (Bucholtz \& Hall, 2005), it is not a sufficient condition for developing a common identity. For example, the development of a common social identity requires that 
individuals share economic, political, cultural or other social histories and conventions for displaying socially recognized behaviors and attitudes, and associating these with the focal social identity (Ochs, 1993). This notion highlights the role of ability in constructing a common identity. In addition, social identity theory holds that individuals can maintain multiple identities according to their affiliation with different groups (Tajfel \& Turner, 1986) and the conception of social identity as manifold is also reflected in sociolinguistic research (e.g., Bucholtz \& Hall, 2005; Ochs, 1993). Although the various identities may not necessarily be incompatible, in a context of power inequalities, such as between non-native and native language speakers (e.g., Peirce, 1995) or representatives from different MNE units (e.g., Vaara, Tienari, Piekkari, \& Säntti, 2005), research suggests that members with majority and minority status have different identity preferences. While majority members are motivated to preserve a single collective identity, minority members prefer to maintain their own distinct identity within the overall collective (Dovidio, Gaertner, \& Saguy, 2009; Mehra et al., 1998). These arguments highlight motivation as another factor for constructing a common identity.

Similarly, the literature has highlighted the unique challenges associated with the receipt of tacit knowledge, often referred to as internal stickiness (Szulanski, 1996). Language differences are a potential cause of such stickiness because tacit knowledge is difficult to articulate and requires extensive personal interaction and effort between exchange parties (Argote \& Ingram, 2000). However, even if both parties speak the same language, subsidiary managers may not necessarily acquire HQ-specific knowledge, for example, because they lack the cognitive structures to understand the knowledge, do not trust the sender or simply resist the transfer (Kostova \& Roth, 2002). Specifically, scholars have argued that a recipient unit requires both an ability to properly understand and make sense of the transferred knowledge, and a motivation to source, accept and adopt knowledge from other MNE units (Gupta \& Govindarajan, 2000; Minbaeva, Pedersen, Björkman, Fey, \& Park, 2003). While existing conceptualizations and operationalizations of both recipient ability and recipient motivation differ and there is debate whether these two factors influence knowledge receipt additively or interactively (Michailova \& Mustaffa, 2012; Song, 2014), they are widely considered to be key predictors.
Below, we develop a moderated mediation model at the subsidiary level that theorizes about how shared language among subsidiary and HQ managers influences subsidiary inflows of tacit knowledge from HQ as an act to construct a shared HQ identity (see Figure 1). In brief, we propose that shared language positively affects tacit knowledge receipt (e.g., Mäkelä et al., 2007), but that the relationship is mediated by two additional factors. First, subsidiary managers require an ability to understand the HQ knowledge, which we conceptualize as the extent to which subsidiary managers share the HQ goals and vision (Orton \& Weick, 1990), hence possessing similar frames of reference to interpret and make sense of the knowledge (Argote \& Ingram, 2000; Brannen, 2004). Second, subsidiary managers require a motivation to gain HQ knowledge, which we conceptualize as the extent to which HR decision making is centralized in the MNE (Bowen \& Ostroff, 2004; Pratt, 1998), thereby making HQ identification more rewarding to subsidiary managers (e.g., Newburry, 2001; Reiche, 2007).

Finally, we consider subsidiary type as a condition under which the ability- and motivation-related factors are more or less salient in mediating the relation between shared language and subsidiary knowledge inflows. Specifically, we expect managers in foreign acquisitions sharing a language with their HQ counterparts to require greater levels of ability and motivation to develop a shared HQ identity through tacit knowledge receipt. This is because managers in foreign acquisitions have relatively less knowledge of the HQ context (Gupta \& Govindarajan, 2000) and are more likely to resist social integration with the parent (Stahl \& Voigt, 2008). Hence, subsidiary type moderates the indirect relationships between shared language and subsidiary knowledge inflows through

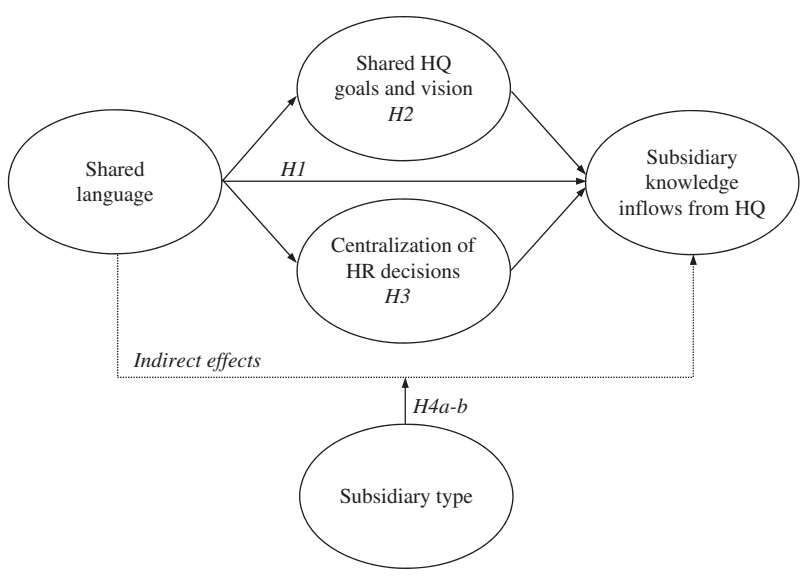

Figure 1 Theoretical model. 
shared HQ goals and vision and centralization of HR decisions, respectively.

\section{HYPOTHESES DEVELOPMENT}

\section{Shared Language and Subsidiary Knowledge Inflows}

For two reasons we would expect subsidiary managers to more likely receive tacit knowledge from HQ to construct a shared identity when sharing a language with their HQ counterparts. First, the transfer of tacit knowledge requires an articulation process that renders the personally held knowledge accessible to others, which makes language a fundamental prerequisite for knowledge transfer (Welch \& Welch, 2008). As most tacit knowledge transfer involves several individuals (Argote \& Ingram, 2000), the more subsidiary and HQ managers share a language, the higher the likelihood that subsidiary managers can access tacit knowledge from HQ. In the case of tacit knowledge, the lack of a shared language also increases the risk of misunderstandings (Slangen, 2011), which will make it more difficult for subsidiary managers to develop accurate perceptions of the HQ identity and construct a shared identity based on the acquired knowledge. Second, the more subsidiary and HQ managers share a language, the easier it will be for subsidiary managers to consider the $\mathrm{HQ}$ as part of the same language-based in-group (Mäkelä et al., 2007). As a result, they are more likely to invest in developing a sense of belonging toward and identification with HQ (Kostova \& Roth, 2002). One way to achieve this is by receiving knowledge from HQ that allows them to understand HQ conventions (Ochs, 1993) and hence operate in line with HQ. Empirical research indeed suggests that language commonalities positively affect knowledge flows, even when controlling for differences in culture (e.g., Schomaker $\&$ Zaheer, 2014). Taken together, we propose:

Hypothesis 1: Shared language among subsidiary and HQ managers will be positively related to subsidiary knowledge inflows from HQ.

\section{Shared HQ Goals and Vision as a Mediator}

Despite sharing a language with their HQ counterparts, subsidiary managers may not be able to understand the tacit HQ knowledge to construct a shared HQ identity. From a social identity perspective, scholars have pointed out that the development of a common social identity requires individuals to share economic, political, cultural or other social histories and conventions for displaying socially recognized behaviors and attitudes, and associating these with the focal social identity (Ochs, 1993). In the MNE context, research suggests that subsidiary managers who have relatively less familiarity with the MNE as a whole are less likely to develop a shared identity with other MNE units (Vora \& Kostova, 2007).

One way in which HQ can actively help subsidiary managers to better understand the HQ knowledge and apply it toward the construction of a shared HQ identity is to establish clear goals and vision that are commonly understood and accepted across the MNE. In general, common goals are thought to bind together loosely coupled and spatially dispersed parts of an organization and facilitate inter-unit cooperation (Orton \& Weick, 1990). Common goals and vision also increase the relatedness of frames of reference, interpretational schemas and systems of understanding (Argote \& Ingram, 2000; Brannen, 2004). This will allow subsidiary managers to better understand the intricacies of the HQ's knowledge context and derive meaning from it for their identity construction, particularly in the case of tacit knowledge (Bhagat et al., 2002). Sharing HQ goals and vision may also reduce subsidiary managers' uncertainty regarding the value of tacit HQ knowledge because they feel more confident that they can properly understand and apply the knowledge in their own context (Nahapiet \& Ghoshal, 1998).

Similarly, the literature has suggested that MNE knowledge flows benefit from establishing a dominant logic for decision making (e.g., Verbeke, 2010). A dominant logic concerns the frames of reference and mindsets that managers have developed over time as a result of interpreting and experiencing organizational situations and allows managers to act in a unified manner and make consistent decisions (Prahalad \& Bettis, 1986), and is therefore conceptually related to shared HQ goals and vision. Because a shared language provides common lexical, syntactical and phonetic structures to express and understand each other (Tenzer \& Pudelko, 2012), it forms the basis for subsidiary managers to adopt a dominant logic from HQ. In turn, this should also assist subsidiary managers to receive tacit HQ knowledge for constructing a common HQ identity and applying this dominant logic in line with HQ.

Empirical evidence further supports our argument that shared language relates to tacit knowledge receipt through common goals and vision. First, 
language commonalities among subsidiary and $\mathrm{HQ}$ managers have been found to facilitate the emergence of a shared vision (Barner-Rasmussen \& Björkman, 2007). Second, a shared understanding of the organization's goals allows knowledge senders and recipients to communicate with fewer misunderstandings when discussing firm-specific practices and routines (Tsai \& Ghoshal, 1998).

Hypothesis 2: The extent to which subsidiary managers share HQ goals and vision will mediate the positive relationship between shared language among subsidiary and HQ managers and subsidiary knowledge inflows from HQ.

\section{Centralization of HR Decisions as a Mediator}

Despite sharing a language with their HQ counterparts, subsidiary managers may also not be motivated to acquire tacit HQ knowledge to construct a shared HQ identity. From a social identity perspective, research on second language acquisition (e.g., Peirce, 1995) suggests that language learners want to speak not only to exchange information but also to make sense of contextual knowledge about how they relate to their social context. Speaking a shared language thus requires a commensurate return on one's investment in the second language, for example, by becoming part of an attractive social identity (Peirce, 1995). In the MNE context, evidence suggests that subsidiary managers need to be motivated to receive tacit HQ knowledge (e.g., Minbaeva et al., 2003), necessary for constructing a shared HQ identity. We therefore propose that subsidiary managers' motivation to acquire HQ knowledge should also mediate the relationship between shared language and subsidiary knowledge inflows.

One way in which HQ can motivate subsidiary managers to construct a shared HQ identity by receiving tacit $\mathrm{HQ}$ knowledge is to increase the relative salience of the HQ identity. This is because individuals that hold multiple identities strive for self-enhancement, which requires group identification to be rewarding (Pratt, 1998). Increasing the salience of the HQ identity does not necessarily diminish subsidiary managers' local identity (Vora $\&$ Kostova, 2007). However, research suggests that group members with minority status, as in the case of subsidiary managers within the wider MNE, often prefer to preserve their own distinct status within the overall collective (Dovidio et al., 2009; Mehra et al., 1998). Hence only if subsidiary managers believe that identification with the superordinate HQ group is rewarding, will they be motivated to acquire the tacit knowledge from HQ necessary to construct a shared HQ identity.

HQ can make subsidiary managers' HQ identification rewarding by centralizing HR decision making. In general, scholars have pointed to HR practices as an important source of identification (Ellemers et al., 2004). While some HR-related decisions are a function of the local institutional environment, there is substantial leeway in how much centralization is possible in MNEs (Schuler, Budhwar, \& Florkowski, 2002). In general, centralization carries potential drawbacks as it may lead to inertia, stifle creativity and reinforce structural inequalities in the distribution of power (e.g., Mudambi \& Navarra, 2004; Vermeulen \& Barkema, 2001). However, and for our study more importantly, evidence also suggests a positive relationship with subsidiary inflows of tacit knowledge (Gupta \& Govindarajan, 2000). In the case of HR decision making, there are further important benefits of centralization. For example, when decisions about performance appraisal, training and development, promotions or compensation are made centrally rather than locally, subsidiaries are less detached from the wider MNE, leading subsidiary employees to perceive greater career prospects in the entire organization (Newburry, 2001). Scholars have also argued that the centralization of pay practices and the management of a central roster of talent within the MNE will provide subsidiary managers with more opportunities for international mobility (Festing, Engle, Dowling, \& Sahakiants, 2012; Reiche, 2007).

Related research supports our prediction that shared language affects subsidiary knowledge inflows through centralization of HR decisions. Specifically, a shared language is thought to make the diffusion and implementation of centralized decisions easier (Marschan-Piekkari et al., 1999a). Similarly, evidence suggests that the design of $\mathrm{HR}$ practices directly influences cross-unit inflows of tacit knowledge (Yamao, De Cieri, \& Hutchings, 2009). Scholars have also highlighted the role of employee consensus toward HR decisions for a number of positive outcomes, including knowledge transfer (Bowen \& Ostroff, 2004). In cross-unit knowledge exchanges, such consensus requires a centralized HR system rather than the experience of different HR systems across units.

Hypothesis 3: The extent to which HR decisions are centralized will mediate the positive relationship between shared language among subsidiary and HQ managers and subsidiary knowledge inflows from $\mathrm{HQ}$. 


\section{Subsidiary Type as a Moderator}

Finally, we propose that subsidiary type will moderate the indirect relationships between shared language and subsidiary knowledge inflows through shared HQ goals and vision, and through centralization of HR decisions, respectively. It has been common to differentiate subsidiary type according to the MNE's mode of entry into a foreign country, distinguishing between foreign greenfield investments and foreign acquisitions (e.g., Harzing, 2002). Subsidiary type should affect the salience of the abilityand motivation-related mediators of the relation between shared language and subsidiary inflows of tacit knowledge because managers in foreign greenfields and foreign acquisitions are likely to have different identity preferences (Vora \& Kostova, 2007). Specifically, as foreign acquisitions have existed as a collective unit before acquisition they are more likely to maintain a social identity that is unaligned with that of HQ compared with foreign greenfields (Vaara et al., 2005). We therefore expect managers in foreign acquisitions sharing a language with their HQ counterparts to require greater levels of ability and motivation to develop a shared HQ identity through tacit knowledge receipt.

First, compared with foreign greenfields it will be more important for managers in foreign acquisitions to be able to receive tacit knowledge from HQ. This is because foreign acquisitions have relatively less overlapping knowledge bases with HQ (Gupta \& Govindarajan, 2000; Vermeulen \& Barkema, 2001) and, hence, managers in foreign acquisitions possess relatively less tacit knowledge of the HQ context that would be necessary to construct a shared HQ identity. As outlined above, HQ can enable subsidiary managers to better understand and apply HQ knowledge by establishing shared HQ goals and vision. Therefore we expect that the mediation of shared HQ goals and vision will be stronger in foreign acquisitions compared with foreign greenfields.

Hypothesis 4a: Subsidiary type will moderate the positive and indirect relationship between shared language among subsidiary and HQ managers and subsidiary knowledge inflows from $\mathrm{HQ}$ through shared HQ goals and vision. Specifically, the mediation of shared HQ goals and vision will be stronger in foreign acquisitions compared with foreign greenfields.

Second, compared with foreign greenfields it will also be more important for managers in foreign acquisitions to be motivated to receive tacit knowledge from HQ. According to social identity theory
(Tajfel \& Turner, 1986; Turner, 1982), individuals are particularly prone to maintaining a positive social identity by idealizing their own group and denigrating the other group under conditions of perceived external threat, as is the case in a foreign acquisition. Research indeed suggests that managers in foreign acquisitions will have weaker attachment toward HQ managers (Li, 1995) and are more likely to resist social integration with the parent compared with foreign greenfields (Stahl \& Voigt, 2008). Hence making HQ identification rewarding through a centralization of HR decisions will be more salient in foreign acquisitions. In sum, we also expect the mediation of centralization of HR decisions to be stronger in foreign acquisitions compared with foreign greenfields.

Hypothesis 4b: Subsidiary type will moderate the positive and indirect relationship between shared language among subsidiary and HQ managers and subsidiary knowledge inflows from HQ through centralization of HR decisions. Specifically, the mediation of centralization of HR decisions will be stronger in foreign acquisitions compared with foreign greenfields.

\section{METHOD}

\section{Sample and Procedure}

To test our hypotheses, we collected data through both online and paper questionnaires in nine different countries/regions (see Table 1 for an overview). In Australia/New Zealand, China, Japan, the United Kingdom, Spain and Germany, we mailed the surveys locally and in collaboration with local universities. Surveys to France and the Nordic countries (Denmark, Finland, Norway, Sweden) were mailed from the United Kingdom. Respondents received an initial mailing and one reminder, although budget limitations meant that we could only send reminders to a third of the companies in the United Kingdom. We had initially hoped to collect all data online, but soon realized that some respondents were uncomfortable with this. Thus we decided to offer a paper version as an alternative in most countries. To account for potential differences in data collection methods (Simsek \& Veiga, 2001), we ran $t$-tests for all variables in our study for those countries in which both paper and online questionnaires were used. In most countries, no significant differences were found between the two versions. Although minor differences appeared in the United Kingdom, Australia/New Zealand, Germany and Spain, these were most likely caused by over- or 
Table 1 Sample distribution across subsidiary location, industry and HQ location

\begin{tabular}{|c|c|c|c|}
\hline Subsidiary location & $\begin{array}{l}\text { Number of } \\
\text { respondents }\end{array}$ & Industry & $\begin{array}{l}\text { Number of } \\
\text { respondents }\end{array}$ \\
\hline Australia/New Zealand & 92 & Banking \& insurance & 20 \\
\hline China & 91 & Business services & 78 \\
\hline France & 70 & Chemicals & 129 \\
\hline Germany & 125 & Food \& beverages & 55 \\
\hline Japan & 80 & Industrial machinery & 130 \\
\hline Korea & 118 & Measuring \& analysing instruments & 30 \\
\hline Nordic countries & 71 & Motor vehicles \& parts & 138 \\
\hline Spain & 82 & Paper \& allied products & 33 \\
\hline United Kingdom & 88 & Pharmaceuticals & 73 \\
\hline \multirow{2}{*}{ HQ location } & Number of & Rubber \& plastics & 60 \\
\hline & respondents & Other & 71 \\
\hline $\begin{array}{l}\text { (<10 respondents omitted) } \\
\text { Austria }\end{array}$ & 14 & Official corporate language & $\begin{array}{l}\text { Number of } \\
\text { respondents }\end{array}$ \\
\hline Belgium & 14 & English & 552 \\
\hline Denmark & 14 & None & 193 \\
\hline France & 67 & Japanese & 35 \\
\hline Finland & 19 & German & 13 \\
\hline Germany & 107 & French & 10 \\
\hline Italy & 18 & Chinese & 6 \\
\hline Japan & 89 & Korean & 3 \\
\hline Netherlands & 35 & Italian & 2 \\
\hline Norway & 11 & Czech & 1 \\
\hline Singapore & 13 & Hebrew & 1 \\
\hline Sweden & 28 & Spanish & 1 \\
\hline Switzerland & 42 & & \\
\hline United Kingdom & 56 & & \\
\hline United States & 222 & & \\
\hline Other & 68 & & \\
\hline Total & 817 & Total & 817 \\
\hline
\end{tabular}

under-representation of culturally and linguistically closer HQ countries for one of the versions. Overall, we can therefore assume that the method of data collection did not significantly affect our results.

As questionnaires in English can conceal national differences by reducing variance (Harzing et al., 2005), we translated our questionnaire into the respective local language of the subsidiary country. The Nordic countries were the only exception because we expected the English language capacity of our respondents to be sufficiently high to provide reliable responses in English. Overall, we translated our survey instrument into Chinese, Japanese, Korean, German, French and Spanish. Bilingual research assistants conducted the initial translation under the supervision of the project coordinator. In a subsequent step, we organized focus group interviews that involved both the translator and two or three other bilingual students to discuss the translated questionnaire. These focus groups consisted of first asking the bilingual students to carefully review each translated item one by one and assess whether the text appeared "natural" to them. They were then asked to review the original English item and indicate whether it was equivalent to the corresponding native version. Whenever at least one student considered an item to be not entirely equivalent the translator prompted a discussion between the 
participants to arrive at a better translation. The project coordinator attended each focus group to explain the meaning of the items where necessary. The entire process lasted a minimum of $3 \mathrm{~h}$ per language, while the Asian languages usually required three sessions lasting up to $8 \mathrm{~h}$ in total.

We mailed the questionnaires to the Head of HR of all majority owned subsidiaries with more than 100 employees. We pre-selected the set of industries included in our sample such that they would have a sufficient representation across both home and host countries to avoid attributing industry differences to home/host country distribution effects. Addresses for all countries were acquired from D\&B (formerly Dun \& Bradstreet). The choice of HR managers as our respondents was motivated by several reasons. First, we expected HR managers to most likely be knowledgeable about the variety of topics in our study. Second, most surveys to MNE subsidiaries are targeted at managing directors which is why we expected a survey directed to a functional manager to result in a higher response rate, while also entailing less risk that someone else would fill out the survey on behalf of the intended respondent. Third, out of all functions we expected HR managers to most likely be a local manager. This helped to reduce the potential bias of having a mix of host country nationals and expatriate respondents, which is particularly important for a study about subsidiary perceptions of shared language and social identity regarding HQ. Our results showed that $95 \%$ of the HR managers were host country nationals, a higher share than any of the other functions. Finally, previous research suggests that HR managers' assessments of subsidiary knowledge inflows are highly consistent with the assessments of other subsidiary executives (Chang et al., 2012).

After eliminating undeliverable surveys, we achieved an overall response rate of $13.83 \%$. This response rate is fairly common for multi-country studies (Harzing, 1997). The response rates in our study varied from $4.0 \%$ for China to $47.6 \%$ for Korea. The latter is likely to reflect the different data collection method employed in this country (given the lower amount of foreign subsidiaries in Korea we commissioned an agency to call and prompt subsidiary executives to fill out our questionnaires). To test for the possibility that the use of an external agency for data collection may bias our results, we also analyzed our data without the Korean sample. As none of the substantive results change, we decided to retain the Korean sample. The low response rate in China was probably caused by the fact that China was the only country in which we did not use paper questionnaires. Response rates in China were further reduced due to a government policy of restricting access to foreign websites with Chinese page titles. As a result, once our website was blocked, we received no further responses in our initial mailing in China. However, as we had expected a relatively lower response rate in China, we sent the highest number of questionnaires in this country, achieving a satisfactory response at least in absolute terms. The United Kingdom and France also obtained low response rates. In the United Kingdom, this might have been caused by the lack of a full reminder and the result of our data being collected in the height of the Global Financial Crisis. In multicountry studies France commonly belongs to the countries with the lowest response rates (see Harzing, 1997). Although we included a recommendation letter from one of France's most prestigious business schools to alleviate this concern, not being able to conduct the mailing locally might have negatively affected our response rates.

We conducted two sets of analyses to test for the potential of non-response bias. First, we compared the size and age of the subsidiaries that responded with those that did not respond. We found no significant differences for either subsidiary size in terms of number of employees (581.25 vs 586.15 , $p=0.96)$ or year of establishment (1982.53 vs $1984.42, p=0.123)$. Second, for each country we compared respondents to the initial mailing with those that reacted to the reminder for all study variables. Late respondents are often considered to be more representative of non-respondents than early respondents (Armstrong \& Overton, 1977). Again, we found no systematic significant differences for any of our variables. As a result, non-response bias does not seem to be a problem in our study.

We obtained substantial sample sizes in each of the nine countries/regions that our study included, and a good coverage of industries. Table 1 presents the final sample by subsidiary and HQ location, industry and official corporate language use. With regard to subsidiary characteristics, the mean for the year of establishment was 1989, its median 1996. On average subsidiaries had 602 employees, while the median was $192 ; 41 \%$ of the subsidiaries were foreign greenfields and 59\% foreign acquisitions.

\section{Measures}

All variables were measured on 7-point Likert scales. We used different scale anchors for each of our 
substantive variables to reduce the potential of common method bias.

\section{Independent variable}

To operationalize shared language among subsidiary and HQ managers, ideally we would have liked to measure the shared language between each actual knowledge sender and recipient. However, for an organization-level study that spans a large number of MNE subsidiaries and countries, the collection of data on each individual instance of tacit knowledge transfer and its subsequent aggregation would not have been feasible. We therefore developed a subjective measure at the subsidiary level consisting of four questions (see also the Appendix), asking respondents to assess the language capability of (1) subsidiary managers in the language spoken in the HQ country, (2) subsidiary managers in the official corporate language, (3) HQ managers in the language spoken in the country the focal subsidiary is located in and (4) HQ managers in the official corporate language $(1=$ very poor, $7=$ native speaker $)$. We then summed up the scores of all four variables per respondent to create an aggregate score at the subsidiary level. To aid with the interpretation, we transformed our measure into a metric ranging from 0 to 1 by dividing the measure by its maximum score of 28 .

Our subjective measure of shared language has a number of advantages over objective, country-level measures used in previous research (e.g., Dow \& Karunaratna, 2006; Slangen, 2011). First, not having to rely on country scores means we do not have to assume that language competencies are homogenous throughout the countries in question. Instead, we tap directly into the language competencies available in the particular companies. Second, our measure reflects a conceptualization of shared language that is not limited to one specific language as it potentially captures up to three languages: the home country language, the host country language or the corporate language. In this vein, our subjective measure also implicitly accounts for the use of English as a second language because in many cases English serves as the official corporate language (in $68 \%$ of the cases in our sample, see Table 1 ).

Third, objective measures of shared language draw on the notion that the closer languages are to each other the more people can understand each other. However, even reasonably close languages may prevent communication unless the counterparts either have knowledge of their counterparts' language or can revert to a third, common language. For example, Germany and the Netherlands are relatively close to each other in terms of their objective language proximity scores (Dow \& Karunaratna, 2006), yet that does not mean their native speakers can necessarily communicate with each other better than individuals from Germany and Spain, who are more distant.

Fourth, objective measures of shared language (e.g., Slangen, 2011) do not necessarily account for language fractionalization (e.g., Alesina, Devleeschauwer, Easterly, Kurlat, \& Wacziarg, 2003). Our subjective measure implicitly accounts for fractionalization because respondents can choose the language that is most relevant in their context. For example, our item "How would you assess the language capability of HQ managers in the language spoken in the country the focal subsidiary is located in" would lead a respondent to choose German if the HQ was located in the Germanic part of Switzerland, and French if the HQ was located in the French part of Switzerland. Fifth, we argue that a subjective language measure is also more appropriate in the specific context of our research. As we are adopting a social identity perspective, which is based on subjective phenomena such as impressions, attitudes and feelings, what ultimately matters are subjective evaluations of shared language and not objective measures.

\section{Mediator and moderator variables}

To measure shared HQ goals and vision, we constructed a 3-item scale based on Tsai and Ghoshal (1998): "Managers in this subsidiary are enthusiastic about pursuing the collective goals of the whole organization," "This subsidiary's managers have the same ambitions and vision as managers at $\mathrm{HQ}^{\prime \prime}$ and "This subsidiary's organizational culture and management style is very similar to that at HQ" $(1=$ strongly disagree, $7=$ strongly agree $)$. We averaged all items to form a scale score $(\alpha=0.80)$. We measured centralization of HR decisions with six items. We asked respondents "Who would normally have the decision-making authority regarding the following HR functions?" ( $1=$ subsidiary alone, $7=H Q$ alone $)$ and provided them with a list of the following six different HR functions: recruitment and selection, training and development, performance appraisal, compensation, promotion and general HR strategy. Again, we averaged all six items to create a scale score $(\alpha=0.89)$. We operationalized subsidiary type through a dichotomous variable $(0=$ foreign acquisition, 1 = foreign greenfield).

\section{Dependent variable}

To operationalize subsidiary knowledge inflows from $H Q$, we built on Gupta and Govindarajan's (2000) 
measure of tacit knowledge flows. Accordingly, we asked respondents to what extent their subsidiary receives knowledge from HQ in the area of (1) R\&D, (2) manufacturing, (3) distribution/logistics, (4) marketing/sales, (5) HRM and (6) service delivery (1 = not at all, $7=$ very $m u c h)$. All six items were averaged to form a scale score $(\alpha=0.85)$.

\section{Control variables}

We controlled for several variables to improve our model estimation. We included measures for subsidiary size, operationalized as the logarithmic transformation of the number of employees and subsidiary age (in years). We also asked respondents to indicate the subsidiary's function (R\&D, manufacturing, sales/marketing, distribution/logistics, service, national/regional HQ). As many subsidiaries served several of these functions we controlled for whether the subsidiary serves any of these functions within the MNE $(0=N o, 1=Y e s)$. In addition, we controlled for two aspects of the relational context in which the knowledge flows take place (Szulanski, 1996). First, we controlled for the ratio of expatriates that were working in the subsidiary at the time of data collection relative to total subsidiary staff as expatriates contribute to cross-unit knowledge flows (Reiche et al., 2009). Second, given that direct interactions between sender and recipient are thought to particularly facilitate the receipt of tacit knowledge (Argote \& Ingram, 2000), we also controlled for frequency of face-to-face interactions between subsidiary and HQ managers (Mäkelä \& Brewster, 2009). Specifically, we asked our respondents to rate the frequency of subsidiary managers' interactions with HQ staff in four contexts, including business trips to HQ, participation in committees and task forces, participation in training programs, and participation in meetings and conferences $(1=$ never or hardly ever, $7=$ weekly or more). Subsequently, the four items were averaged to create a scale score $(\alpha=0.82)$.

To explicitly test for the superiority of our subjective measure of shared language over existing objective measures, we also controlled for country-level language proximity by computing proximity scores between each respective native language of the HQ and the subsidiary country, building on the composite scale of language distance developed by Dow and Karunaratna (2006). To interpret our results in terms of closeness rather than distance, we subsequently transformed the scale into proximity scores. Further, given that English might be used as a lingua franca (e.g., Planken, 2005) even if English is neither the official corporate language nor one of the home or host country languages, we also controlled for the similarity in country-level capabilities in English between the HQ and subsidiary countries. In line with previous research (Slangen, 2011), we took the scores reached by examinees from each of the HQ and subsidiary countries included in our sample on the Test of English as a Foreign Language (TOEFL), the most widely accepted test of spoken and written English in the world. We used the average TOEFL scores that each respective group of examinees achieved on the paper-based test in 2008, the year in which our data collection began. For countries whose native language is English, we used the average test score of native English speakers. To arrive at our measure of proximity of English capabilities, we computed proximity scores between the average test scores of the subsidiary and the HQ countries.

Finally, we examined possible response differences across the nine subsidiary locations. To do so, we computed the ICC score for our three endogenous variables (shared HQ goals and vision, centralization of HR decisions, subsidiary knowledge inflows) to assess the within- and between-group variance. The ICC(1) scores have values of 0.018 for shared HQ goals, 0.094 for HR centralization and 0.065 for knowledge inflows, respectively. Although these scores are moderate, two are above the recommended value of 0.05 (see Bliese \& Hanges, 2004), pointing to the need to explicitly account for our data being nested within countries. We also probed for a possible nesting of our data with regard to industry affiliation. The corresponding ICC(1) scores are -0.007 for shared HQ goals, 0.018 for centralization of HR decisions and 0.011 for knowledge inflows, respectively, suggesting that industry effects are not an issue in our data set. Still, we included industry affiliation as a fixed effect in our analyses.

\section{RESULTS}

\section{Preliminary Analyses}

To evaluate the discriminant validity of all multiitem variables measured in the survey (shared language, shared HQ goals and vision, centralization of HR decisions, subsidiary knowledge inflows), we first conducted a series of confirmatory factor analyses (CFAs) with AMOS (Arbuckle \& Wothke, 1999). As shown in Table 2 , the fit indices reveal that the hypothesized four-factor model fits our data well and, importantly, is significantly better fitting than any of the alternative nested models, indicating support for the distinctiveness of our constructs. 
Table 2 Results of CFA for the survey measures ${ }^{\mathrm{a}}$

\begin{tabular}{|c|c|c|c|c|c|}
\hline Model & $\chi^{2}$ & df & TLI & CFI & RMSEA \\
\hline Four-factor model & 709.49 & 146 & 0.89 & 0.92 & 0.06 \\
\hline Three-factor model: Shared HQ goals and vision and centralization of HR decisions combined & 863.74 & 147 & 0.86 & 0.89 & 0.07 \\
\hline Three-factor model: Shared language and shared HQ goals and vision combined & 1012.59 & 147 & 0.83 & 0.87 & 0.08 \\
\hline Two-factor model: All three predictors combined & 1114.03 & 149 & 0.81 & 0.85 & 0.09 \\
\hline One-factor model & 1165.57 & 152 & 0.81 & 0.85 & 0.09 \\
\hline
\end{tabular}

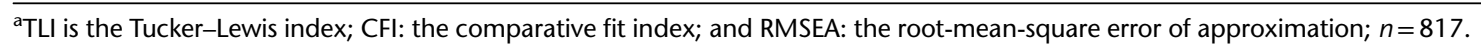

To assess the quality of our survey translations, we tested for invariance of our measures across the seven survey language groups (English, Chinese, Japanese, Korean, German, French and Spanish). The relatively low sample size in some of the language groups did not allow us to conduct more sophisticated tests for language equivalence across all groups simultaneously. However, separate multigroup CFAs of our four-variable measurement model for each of the seven survey language groups showed acceptable fit (survey language group-specific RMSEAs ranged from 0.05 to 0.09 ) and were significantly better fitting than any of the alternative nested models specified in Table 2 . In addition, we detected no systematic bias in the survey language group-specific reliability coefficients, and the reliability coefficients of our three multi-item scales for each of the seven survey language groups, except for subsidiary knowledge flows in China $(\alpha=0.67)$, were all above the threshold level of 0.70. To test for the possibility that the lower reliability of our dependent variable in the Chinese subsample may bias our results, we also analyzed our data without the Chinese data. As none of the substantive results change, we decided to retain the Chinese sample. Taken together, we conclude that our data does not suggest any evidence of substantial language variance.

Given our perceptual data, we took several preventive measures to minimize the potential of common method bias (Podsakoff, MacKenzie, Lee, \& Podsakoff, 2003), including the separation of items for the independent and dependent variables into different sections of the questionnaire and the use of different scale endpoints. It is important to note that common method variance acts as a main effect. As a result, it only inflates zero-order correlations but does not inflate the possibility of falsely detecting moderator variables (Podsakoff et al., 2003). Before testing our hypotheses, we also performed two sets of preliminary analyses to assess the potential for common method bias in our sample. First, we performed Harman's single-factor test (Podsakoff et al., 2003) and inspected the unrotated solution of an exploratory factor analysis with items of our five substantive variables. The first factor accounted for only $24.26 \%$ of the variance, compared with $64.41 \%$ of the variance explained by all five factors.

Second, we followed Lindell and Whitney's (2001) recommendations to test for common method bias by introducing a marker variable. Such a marker should be measured by the same instrument as the scales used in the analysis and should be theoretically unrelated to the substantive variables in the study. For our purposes, the variable "perceived subsidiary staff morale and retention relative to the subsidiary's local competitors" (2-item scale, $\alpha=0.79$ ) was chosen as a marker variable because we did not use this variable in our analyses, we did not expect a theoretical relationship to the other substantive variables and because it was measured in a similar way as most of our other variables. When examining the partial correlations between all perceptual variables, controlling for perceived subsidiary staff morale and retention, we found that all significant correlations in Table 3 remained significant. Overall, these tests provide confidence that common method bias is unlikely to be an issue in our study. Table 3 reports means, standard deviations and correlations among the variables in this study. The correlations are low to moderate, further suggesting that common method bias is unlikely to be a major issue.

Finally, we tested for the possibility that shared language is endogenously determined. Specifically, it is possible that shared language is a function of whether or not a firm has an official language mandate and that the latter variable may have led to sample selectivity in our study. Accordingly, we ran a two-stage Heckman correction analysis (Heckman, 1979) with STATA 10.0 (Rabe-Hesketh \& Skrondal, 2008). In the first-stage logit model, the dependent variable is a dummy that takes the value 1 if the firm has an official corporate 


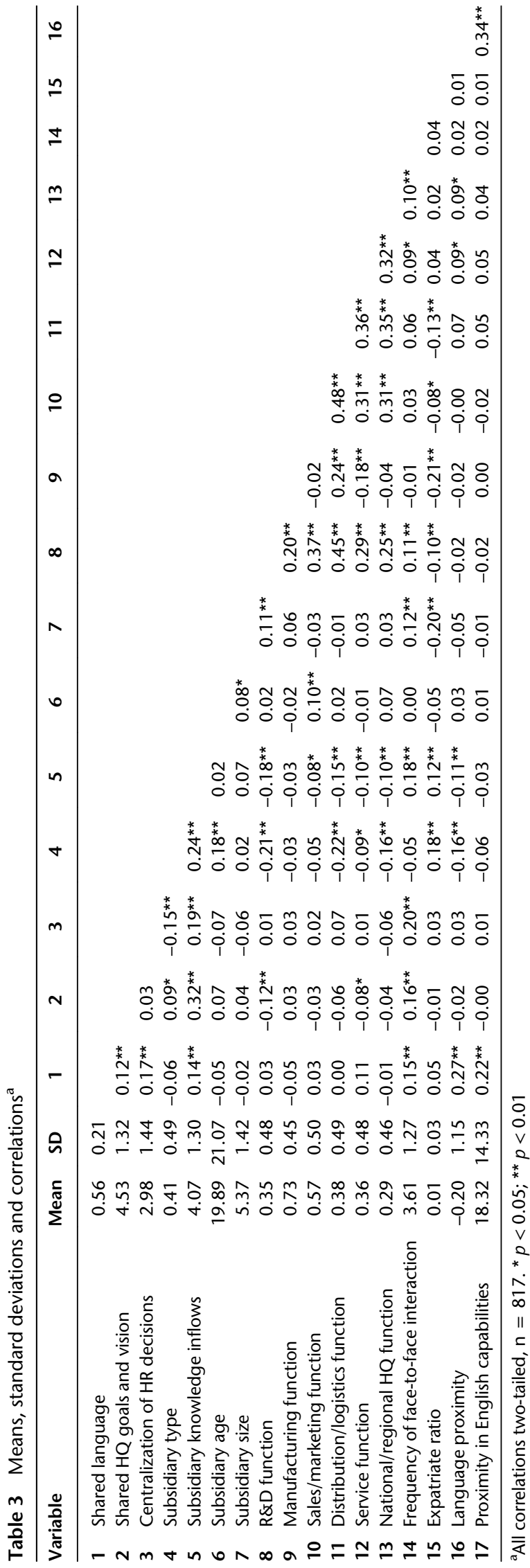

language and 0 otherwise. This is regressed on various firm-specific and industry variables that could affect the firm's decision to have an official corporate language. The first stage of the Heckman procedure yields a propensity score of the decision to have an official corporate language. This score is then used to obtain estimates of the correction for selectivity, or $\lambda$, which corresponds to the inverse Mill's ratio (Cameron \& Trivedi, 2009). The second-stage regression is similar to the original regression of subsidiary knowledge inflows on our control and substantive variables except that it includes an additional control variable that is instrumental for the dummy of official corporate language, and hence corrects for selectivity $(\lambda)$. The results indicate that the coefficient of $\lambda$ is nonsignificant $(\lambda=0.53$, s.e. $=0.74, p>0.05)$, suggesting that sample selectivity based on whether or not a firm has an official corporate language is unlikely to be an issue in our study.

\section{Tests of Hypotheses}

To test our hypothesized relationships, we conducted a set of random-intercept maximum likelihood regression models using STATA 10.0. For each regression, we estimated a random-intercept model to account for the fact that our data are nested within countries. In addition, we accounted for industry affiliation as a fixed effect using 14 dummy variables. To reduce the potential of multicollinearity that may arise when creating interaction terms from two other predictors and to make the coefficients easier to interpret, we centered the substantive independent and moderator variables before creating interaction terms (Aiken \& West, 1991). ${ }^{1}$ Tables 4 and 5 summarize the regression results for subsidiary knowledge inflows and the mediator variables.

To test Hypothesis 1, we regressed subsidiary knowledge inflows on 12 controls (subsidiary age, subsidiary size, six subsidiary functions, frequency of face-to-face interaction, expatriate ratio, language proximity, proximity in English capabilities) while accounting for the industry dummies (entered in Step 1), and shared language (entered in Step 2). As shown in Table 4, Model 2, shared language was significantly positively related to subsidiary knowledge inflows, supporting Hypothesis 1 .

To test Hypotheses 2 and 3, we conducted a formal significance test of the indirect relationships between shared language and subsidiary knowledge inflows through shared HQ goals, and between shared language and subsidiary knowledge inflows through centralization of HR decisions. To avoid 
power problems due to asymmetric and other nonnormal sampling distributions of an indirect effect (MacKinnon, Lockwood, \& Williams, 2004), we computed bootstrapped confidence intervals (CIs). Bootstrap results (bootstrap sample size $=5000$ ) of the formal two-tailed significance test, controlling for centralization of HR decisions, showed a significant indirect effect of shared language on subsidiary knowledge inflows through shared HQ goals (Value = 0.29 , bootstrapped s.e. $=0.07, z=3.94, p<0.01$ ), with a bootstrapped $95 \% \mathrm{CI}$ around the indirect effect not containing zero $(0.15,0.43)$. Controlling for shared HQ goals, we also found a significant indirect effect of shared language on subsidiary knowledge inflows through centralization of HR decisions (Value $=0.09$, bootstrapped s.e. $=0.05, z=2.05, p<0.05)$, with a bootstrapped $95 \% \mathrm{CI}$ around the indirect effect not containing zero $(0.01,0.18)$. Further, according to Table 5, Models 2 and 6, shared language was significantly positively related to both shared HQ goals and centralization of HR decisions. In addition, as demonstrated in Table 4, Model 3, both shared HQ goals and centralization of HR decisions positively and significantly related to subsidiary knowledge inflows once shared language was taken into account. Taken together, these results support Hypotheses 2 and 3.

Hypotheses $4 \mathrm{a}-\mathrm{b}$ predicted that the indirect and positive relationships between shared language and subsidiary knowledge inflows through both shared HQ goals and centralization of HR decisions would be weaker in foreign greenfields compared with foreign acquisitions. As this proposed moderated mediation effect implies a direct moderation of subsidiary type, we first simultaneously tested for the possibility of direct, first-stage and second-stage moderation of subsidiary type (Edwards \& Lambert, 2007). Controlling for centralization of HR decisions, bootstrap results revealed a significant firststage moderation of subsidiary type on the relationship between shared language and shared HQ goals ( Value $=-1.19$, bootstrapped s.e. $=0.49, z=-2.42$, $p<0.05)$, but non-significant moderation effects of subsidiary type on the relationships between shared HQ goals and subsidiary knowledge inflows (Value $=-0.01$, bootstrapped s.e. $=0.07, Z=-0.07$,

Table 4 Results of random-intercept regression analysis for subsidiary knowledge inflows ${ }^{\mathrm{a}}$

\begin{tabular}{|c|c|c|c|c|c|c|c|c|}
\hline \multirow[t]{3}{*}{ Variables } & \multicolumn{8}{|c|}{ Subsidiary knowledge inflows } \\
\hline & \multicolumn{2}{|c|}{ Model 1} & \multicolumn{2}{|c|}{ Model 2} & \multicolumn{2}{|c|}{ Model 3} & \multicolumn{2}{|c|}{ Model 4} \\
\hline & $b$ & s.e. & $b$ & s.e. & $b$ & s.e. & $b$ & s.e. \\
\hline Intercept & $4.15^{\text {** }}$ & 0.28 & $4.07^{* \star}$ & 0.28 & $4.08^{* *}$ & 0.28 & $4.05^{* *}$ & 0.28 \\
\hline Subsidiary age & 0.00 & 0.00 & 0.00 & 0.00 & 0.00 & 0.00 & 0.00 & 0.00 \\
\hline Subsidiary size & 0.08 & 0.04 & $0.09^{*}$ & 0.04 & $0.10^{*}$ & 0.04 & $0.10^{*}$ & 0.04 \\
\hline$R \& D$ function & $-0.44^{* *}$ & 0.11 & $-0.45^{\star *}$ & 0.11 & $-0.24^{*}$ & 0.11 & $-0.25^{\star *}$ & 0.11 \\
\hline Manufacturing function & -0.13 & 0.13 & -0.10 & 0.12 & -0.12 & 0.12 & -0.14 & 0.12 \\
\hline Sales/marketing function & 0.11 & 0.11 & 0.11 & 0.11 & 0.00 & 0.11 & 0.01 & 0.11 \\
\hline Distribution/logistics function & -0.15 & 0.13 & -0.17 & 0.12 & -0.12 & 0.11 & -0.13 & 0.12 \\
\hline Service function & -0.08 & 0.12 & -0.13 & 0.12 & -0.07 & 0.12 & -0.07 & 0.11 \\
\hline National/regional HQ function & -0.11 & 0.11 & -0.07 & 0.11 & 0.07 & 0.11 & 0.08 & 0.11 \\
\hline Frequency of face-to-face interaction & $0.23^{* *}$ & 0.04 & $0.21^{* *}$ & 0.04 & $0.13^{* *}$ & 0.04 & $0.13^{* *}$ & 0.04 \\
\hline Expatriate ratio & $4.52^{*}$ & 1.80 & $4.14^{*}$ & 1.77 & 2.64 & 1.73 & 2.78 & 1.72 \\
\hline Language proximity & -0.04 & 0.05 & -0.09 & 0.05 & -0.06 & 0.05 & -0.06 & 0.05 \\
\hline Proximity in English capabilities & 0.00 & 0.00 & 0.00 & 0.00 & 0.00 & 0.00 & 0.00 & 0.00 \\
\hline Shared language & & & $0.90^{* *}$ & 0.23 & $0.61^{* *}$ & 0.23 & $0.61^{* *}$ & 0.22 \\
\hline Shared HQ goals and vision & & & & & $0.26^{\star *}$ & 0.03 & $0.26^{\star *}$ & 0.03 \\
\hline Centralization of $\mathrm{HR}$ decisions & & & & & $0.19 * *$ & 0.03 & $0.20^{* *}$ & 0.03 \\
\hline Subsidiary type & & & & & $0.48^{* *}$ & 0.10 & $0.45^{* *}$ & 0.10 \\
\hline Centralization $\times$ subsidiary type & & & & & & & $-0.15^{\star}$ & 0.06 \\
\hline$\Delta R^{2}$ & & & \multicolumn{2}{|c|}{$0.03^{* *}$} & \multicolumn{2}{|c|}{$0.19^{* *}$} & \multicolumn{2}{|c|}{$0.02^{*}$} \\
\hline$R^{2}$ & \multicolumn{2}{|c|}{0.22} & \multicolumn{2}{|c|}{0.25} & \multicolumn{2}{|c|}{0.44} & \multicolumn{2}{|c|}{0.46} \\
\hline Standard deviation of random effect & \multicolumn{2}{|c|}{$0.23^{* *}$} & \multicolumn{2}{|c|}{$0.20 * *$} & \multicolumn{2}{|c|}{$0.20^{* *}$} & \multicolumn{2}{|c|}{0.20 ** } \\
\hline$\chi^{2}$ & \multicolumn{2}{|c|}{$99.04^{* *}$} & \multicolumn{2}{|c|}{$114.70^{* *}$} & \multicolumn{2}{|c|}{$199.12^{* *}$} & \multicolumn{2}{|c|}{$205.39 * *$} \\
\hline
\end{tabular}

aUnstandardized coefficients are reported, $n=817$. Controls for industry affiliation are included but not reported.

${ }^{*} p<0.05 ;{ }^{* *} p<0.01$. 
Table 5 Results of random-intercept regression analysis for mediators ${ }^{\mathrm{a}}$

\begin{tabular}{|c|c|c|c|c|c|c|c|c|c|c|c|c|}
\hline \multirow[t]{3}{*}{ Variables } & \multicolumn{8}{|c|}{ Shared HQ goals and vision } & \multicolumn{4}{|c|}{ Centralization of HR decisions } \\
\hline & \multicolumn{2}{|c|}{ Model 1} & \multicolumn{2}{|c|}{ Model 2} & \multicolumn{2}{|c|}{ Model 3} & \multicolumn{2}{|c|}{ Model 4} & \multicolumn{2}{|c|}{ Model 5} & \multicolumn{2}{|c|}{ Model 6} \\
\hline & $b$ & s.e. & $b$ & s.e. & $b$ & s.e. & $b$ & s.e. & $b$ & s.e. & $b$ & s.e. \\
\hline Intercept & $4.47^{* *}$ & 0.29 & $4.42^{* *}$ & 0.29 & $4.59^{* \star}$ & 0.30 & $4.56^{\star \star}$ & 0.30 & $3.64 * *$ & 0.32 & $3.60 * *$ & 0.32 \\
\hline Subsidiary age & 0.00 & 0.00 & 0.00 & 0.00 & 0.00 & 0.00 & 0.00 & 0.00 & -0.00 & 0.00 & -0.00 & 0.00 \\
\hline Subsidiary size & 0.05 & 0.04 & 0.05 & 0.04 & 0.04 & 0.04 & 0.04 & 0.04 & -0.04 & 0.04 & -0.04 & 0.04 \\
\hline$R \& D$ function & -0.21 & 0.12 & $-0.24^{*}$ & 0.12 & $-0.29 *$ & 0.12 & $-0.31^{\star}$ & 0.12 & -0.15 & 0.13 & -0.17 & 0.13 \\
\hline Manufacturing function & 0.02 & 0.13 & 0.06 & 0.13 & 0.01 & 0.14 & 0.01 & 0.14 & -0.12 & 0.14 & -0.06 & 0.14 \\
\hline Sales/marketing function & 0.04 & 0.12 & 0.03 & 0.12 & -0.01 & 0.12 & -0.01 & 0.12 & 0.11 & 0.12 & 0.09 & 0.12 \\
\hline Distribution/logistics function & $-0.31^{*}$ & 0.13 & $-0.34^{\star *}$ & 0.13 & -0.26 & 0.13 & $-0.27^{\star}$ & 0.13 & -0.03 & 0.14 & -0.02 & 0.14 \\
\hline Service function & 0.12 & 0.12 & 0.12 & 0.12 & 0.08 & 0.13 & 0.11 & 0.13 & -0.04 & 0.13 & -0.04 & 0.13 \\
\hline National/regional HQ function & -0.12 & 0.12 & -0.12 & 0.11 & -0.03 & 0.12 & -0.01 & 0.12 & $-0.35^{\star *}$ & 0.13 & $-0.31^{*}$ & 0.12 \\
\hline Freq. in face-to-face interaction & $0.21^{\star *}$ & 0.04 & $0.18^{\star *}$ & 0.04 & $0.16^{\star *}$ & 0.04 & $0.16^{\star *}$ & 0.04 & $0.16^{\star *}$ & 0.04 & $0.15^{\star *}$ & 0.04 \\
\hline Expatriate ratio & -1.26 & 1.92 & -1.41 & 1.86 & -2.40 & 1.92 & -2.48 & 1.91 & 3.15 & 2.01 & 2.94 & 1.99 \\
\hline Language proximity & 0.02 & 0.05 & -0.05 & 0.05 & -0.07 & 0.05 & -0.07 & 0.05 & 0.09 & 0.05 & 0.04 & 0.05 \\
\hline Proximity in English capabilities & -0.00 & 0.00 & -0.00 & 0.00 & -0.00 & 0.00 & -0.00 & 0.00 & -0.00 & 0.00 & -0.00 & 0.00 \\
\hline Shared language & & & $1.14^{\star *}$ & 0.24 & $1.19^{\star *}$ & 0.25 & $1.22^{* *}$ & 0.24 & & & $0.55^{*}$ & 0.25 \\
\hline Subsidiary type & & & & & 0.20 & 0.11 & 0.20 & 0.11 & & & & \\
\hline Shared language $\times$ subsidiary type & & & \multirow{2}{*}{\multicolumn{2}{|c|}{$0.05^{* *}$}} & & & $-1.19^{\star}$ & 0.47 & & & & \\
\hline$\Delta R^{2}$ & & & & & \multicolumn{2}{|c|}{0.01} & \multicolumn{2}{|c|}{$0.02^{*}$} & & & \multicolumn{2}{|c|}{$0.01^{*}$} \\
\hline$R^{2}$ & \multicolumn{2}{|c|}{0.12} & \multicolumn{2}{|c|}{0.17} & \multicolumn{2}{|c|}{0.18} & \multicolumn{2}{|c|}{0.20} & \multicolumn{2}{|c|}{0.16} & \multicolumn{2}{|c|}{0.17} \\
\hline Standard deviation of random effect & \multirow{2}{*}{\multicolumn{2}{|c|}{0.12}} & \multicolumn{2}{|c|}{0.10} & \multicolumn{2}{|c|}{0.10} & \multicolumn{2}{|c|}{0.10} & \multicolumn{2}{|c|}{$0.40^{* *}$} & \multicolumn{2}{|c|}{$0.39 * *$} \\
\hline$\chi^{2}$ & & & \multicolumn{2}{|c|}{$76.46^{* *}$} & \multicolumn{2}{|c|}{$78.33^{* *}$} & \multicolumn{2}{|c|}{$84.76^{* *}$} & \multicolumn{2}{|c|}{$65.38^{* *}$} & \multicolumn{2}{|c|}{$67.21^{* *}$} \\
\hline
\end{tabular}

a Unstandardized coefficients are reported, $n=817$. Controls for industry affiliation are included but not reported.

${ }^{*} p<0.05 ;{ }^{* *} p<0.01$.

$p>0.05)$, and between shared language and subsidiary knowledge inflows (Value $=-0.16$, bootstrapped s.e. $=0.46, z=-0.34, p>0.05)$. Model 4 of Table 5 reports the results of regressing shared HQ goals on shared language while taking into account the interaction effect of subsidiary type and shared language. Controlling for shared HQ goals, bootstrap results (bootstrap sample size $=5000$ ) demonstrated a significant second-stage moderation of subsidiary type on the relationship between centralization of HR decisions and subsidiary knowledge inflows (Value $=-0.15$, bootstrapped s.e. $=0.07$, $Z=-2.36, p<0.05)$, but non-significant moderation effects of subsidiary type on the relationships between shared language and centralization of HR decisions $($ Value $=0.05$, bootstrapped s.e. $=0.50$, $Z=0.50, p>0.05)$ and between shared language and subsidiary knowledge inflows (Value $=-0.03$, bootstrapped s.e. $=0.45, z=-0.07, p>0.05$ ). Model 4 of Table 4 reports the results of regressing subsidiary knowledge inflows on our independent and mediator variables while taking into account the interaction effect of subsidiary type and centralization of HR decisions.
Controlling for first-stage moderation of subsidiary type, we then tested the conditional indirect effect of shared language on subsidiary knowledge inflows through shared HQ goals (controlling for centralization of HR decisions). Bootstrap results (bootstrap sample size $=5000$ ) revealed that the indirect effect was positive and significantly different from zero in foreign acquisitions (Value $=0.20$, bootstrapped s.e. $=0.06, z=3.25, p<0.01$ ) but not in foreign greenfields (Value $=0.00$, bootstrapped s.e. $=0.09, z=0.05, p>0.05)$, supporting Hypothesis $4 \mathrm{a}$. Controlling for second-stage moderation of subsidiary type, we also tested the conditional indirect effect of shared language on subsidiary knowledge inflows through centralization of HR decisions (controlling for shared HQ goals). Bootstrap results (bootstrap sample size $=5000$ ) revealed that the indirect effect was positive and significantly different from zero in foreign acquisitions (Value $=0.11$, bootstrapped s.e. $=0.06, z=2.04, p<0.05)$ but not in foreign greenfields (Value $=0.02$, bootstrapped s.e. $=0.05, z=0.43, p>0.05)$, supporting Hypothesis $4 \mathrm{~b}$. Taken together, our data provide support for all our hypotheses. 


\section{DISCUSSION AND CONCLUSION}

In line with social identity theory (Tajfel \& Turner, 1986; Turner, 1982), we conceptualized tacit knowledge receipt as an act to construct a shared HQ identity and found that shared language among subsidiary and HQ managers positively related to tacit knowledge inflows at the subsidiary level. Further, we theorized and empirically showed that the relationship between shared language and subsidiary knowledge inflows is mediated by two variables: shared HQ goals and vision, and centralization of HR decisions. We also considered whether the two mediated relationships are conditional upon subsidiary type. As expected, our results demonstrate that both shared HQ goals and vision, and centralization of HR decisions only mediated the relationship between shared language and subsidiary knowledge inflows in foreign acquisitions but not in foreign greenfields.

While we had hypothesized subsidiary type to moderate the indirect relationship between shared language and subsidiary knowledge inflows, we also found two direct moderation effects. Our results showed a significant negative first-stage moderation of subsidiary type on the relationship between shared language and shared HQ goals and vision, such that the relationship was weaker in foreign greenfields compared with foreign acquisitions. This may reflect the relative ease to diffuse HQ goals and vision to foreign greenfields, as these units allow MNEs to more carefully select the local workforce in terms of whether they can absorb the goals and vision (see Hennart \& Park, 1993). By contrast, we would expect foreign acquisitions to require additional mechanisms for HQ goals and vision to be shared, including a shared language. We also found a significant negative second-stage moderation of subsidiary type on the relationship between centralization of HR decisions and subsidiary knowledge inflows, such that the relationship was weaker in foreign greenfields. While HR centralization comes at the expense of local responsiveness and is, to a certain extent, also limited by the local institutional environment (Schuler et al., 2002), our findings suggest two specific benefits of HR centralization: (1) it motivates subsidiary managers sharing a language with their HQ counterparts to construct a common HQ identity through tacit knowledge receipt, and (2) it also entails additional knowledge benefits in foreign acquisitions, for example by aligning the HR architecture necessary for knowledge to be transferred (see Bowen \& Ostroff, 2004).

\section{Theoretical Implications}

Our findings make several contributions to research on HQ-subsidiary knowledge flows, social identity theory and the literature on sociolinguistics, as well as research on international HRM. First, by theorizing about the mechanisms through which shared language among subsidiary and HQ managers affect subsidiaries' tacit knowledge receipt, our study sheds light on the knowledge benefits that shared language entails in MNEs. Whereas the notion of language commonalities and semantic fit is implicit to resource exchanges in MNEs (e.g., Brannen, 2004), it has received very little empirical attention in the IB literature, with most work being conceptual (Harzing \& Feely, 2008; Nahapiet \& Ghoshal, 1998) or inductive (Buckley, Carter, Clegg, \& Tan, 2005; Mäkelä et al., 2007) in nature. Few, if any, studies have actually drawn on a large-scale sample to test whether and how shared language facilitates MNE knowledge flows. Key to the moderated mediation model that we conceptualized is that shared language is not a sufficient condition for knowledge sharing to occur, particularly in foreign acquisitions. Specifically, we demonstrated that the ability to exchange knowledge, in the form of shared HQ goals and vision, and the motivation to exchange knowledge, in the form of perceived HRrelated opportunities in the wider MNE, play an important mediating role. Whereas previous research has considered the roles of both ability and motivation for MNE knowledge flows (e.g., Minbaeva et al., 2003), this has not yet been sufficiently reflected in the language literature.

We also expand the theoretical bases underlying research on MNE knowledge flows. Thus far, scholars have mainly adopted the knowledge-based view of the firm (e.g., Fang et al., 2010; Yang et al., 2008), with notable other work drawing from additional perspectives such as social capital theory (e.g., Tsai \& Ghoshal, 1998) and organizational learning theory (e.g., Simonin, 2004). These theoretical approaches have so far been limited by studying a subset of relevant types of determinants, often focusing, for example, on characteristics of the transferred knowledge and those of the exchange actors. However, the properties of the relationships between actors or the relational mechanisms in the transfer process have received less attention (Michailova \& Mustaffa, 2012; Song, 2014). Social identity and sociolinguistic explanations of MNE knowledge flows promise to more explicitly integrate these various determinants. Specifically, although we only focused on language as a source of shared identity, we linked the transfer of tacit knowledge, a knowledge characteristic that is 
necessary for constructing a shared social identity, with the language characteristics that exchange actors in the subsidiary and HQ hold and share with each other. In addition, we considered organizational mechanisms such as shared HQ goals and centralized HR decisions through which shared language translates into MNE knowledge flows.

Further, the limited research on social identity in IB has primarily examined a common social identity as an antecedent to knowledge flows (e.g., Björkman et al., 2007; Hinds \& Mortensen, 2005). While we agree in principle with the direction of this relationship, we have theorized why common tacit knowledge also serves as an important prerequisite for developing a shared identity and that knowledge receipt can be conceptualized as an act to construct a common identity because it allows for an understanding of relevant contextual conventions. This suggests that the link between social identity and MNE knowledge flows is more complex and multifaceted than previously assumed. Similarly, while IB scholars have started to caution against regarding shared language policies as a panacea (e.g., Peltokorpi \& Vaara, 2014; Vaara et al., 2005; Volk, Köhler, \& Pudelko, 2014), a more explicit integration of sociolinguistic arguments would help to understand the specific challenges of achieving common language-related benefits, especially tacit knowledge flows and shared identification.

In addition, we developed a new subjective measure to operationalize shared language among subsidiary and HQ managers, which we believe improves on existing societal-level measures of language distance (Dow \& Karunaratna, 2006) or foreign language fluency (Slangen, 2011). Specifically, our measure better reflects language commonalities between exchange parties because it taps into the specific actors' competence to communicate in a shared language, rather than assessing only general characteristics of both parties' native languages or assuming that language competencies are homogenous in a society. At the same time, our measure entails a broader conceptualization of shared language that potentially comprises up to three languages: the home country language, the host country language or the corporate language. We believe that our measure provides a useful instrument to assess shared language in multilingual communication contexts. Empirically, we found that neither of the two objective measures was significantly related to any of our endogenous variables. In fact, the relationship between language proximity and subsidiary knowledge inflows, although nonsignificant, was consistently negative rather than positive. Given that the only countries with a substantial language distance based on Dow and Karunaratna's (2006) measure are the Asian countries and that these countries have relatively high levels of knowledge inflows, the Dow and Karunaratna (2006) measure might simply capture host country effects. Our empirical results hence further support our argument for applying subjective over existing objective measures of shared language.

Second, we also contribute to social identity theory and the sociolinguistic literature by investigating how exactly shared language affects tacit knowledge receipt as an act to construct a shared identity. Indeed, sociolinguistic research has thus far lacked a consensus as to the specific mechanisms that link language and social identity (e.g., Lauring, 2008) and scholars have argued that the relation between language and social identity is conceptually distant (Ochs, 1993), suggesting mediation by more immediate constructs. We contribute to this debate by theorizing and empirically demonstrating that a shared language translates into knowledge receipt as an act to construct a shared identity through both ability- and motivation-related mediators. This notion is particularly useful as it helps to integrate various sociolinguistic arguments underlying the development of a social identity. For example, scholars have highlighted the interactional and relational nature of identity construction for which language is a necessary condition (Bucholtz \& Hall, 2005). Similarly, the literature has pointed to the role of speakers' abilities for understanding language-related behaviors and attitudes and linking them to particular social identities (Ochs, 1993), as well as speakers' language-related motivation and personal investment relevant for social identification (Peirce, 1995).

Our theorizing also expands existing language research in IB that refers to shared identity (e.g., Barner-Rasmussen \& Björkman, 2007; Peltokorpi \& Vaara, 2014) by clearly disentangling the conceptual link between language commonalities and shared identity. Further, by examining the process through which shared language, as one of several salient markers of social identification, can result in identity-related benefits we respond to calls for studying in more detail how social identification occurs (Ashforth et al., 2008).

Third, we contribute to research on international HRM. Scholars have highlighted the importance of HR design for knowledge exchange (e.g., Collins \& Smith, 2006), yet little research has examined the type of HR configurations that are necessary to facilitate MNE knowledge flows (for an exception, 
see Yamao et al., 2009). Given the distinct cultural and institutional contexts it is embedded in, HRM tends to be a relatively more localized function in MNEs. At the same time, scholars have discussed pressures for centralization, for example, to diffuse parent-country HR policies and practices or converge to universal best practices (Edwards \& Kuruvilla, 2005; Pudelko \& Harzing, 2007). Our findings suggest an additional rationale for HR centralization because centralized HR decision making may provide subsidiary managers with the motivation to construct a shared HQ identity through tacit knowledge receipt. Moreover, given the direct moderation of subsidiary type on the relationship between HR centralization and subsidiary knowledge inflows, HR centralization may also entail additional knowledge benefits in foreign acquisitions that go beyond social identity-based explanations. However, as centralization always involves a trade-off with local responsiveness it would be fruitful for future research to explicitly assess the relative performance implications of HQ centralization for the MNE as a whole.

\section{Managerial Implications}

Our study also entails several implications for managerial practice. Conceptualizing knowledge transfer as an act to construct a common identity highlights important additional benefits for the organization. Specifically, subsidiary knowledge receipt not only allows subsidiary members to better achieve their work goals but it may also increase a sense of belonging and solidarity with HQ. As a result, MNEs would be well-advised not to leave the communication with HQ to a few subsidiary managers, for example, expatriates. In companies in which the HQ language is the (explicit or implicit) corporate language, which is often the case for Japanese but also other Asian companies (Harzing \& Pudelko, 2013), existing language barriers may make it more practical to leave $\mathrm{HQ}$-subsidiary communication on both ends to HQ nationals. However, as our results have shown, the inclusion of a wider group of subsidiary managers, in particular locals, at the receiving end of knowledge transfers from HQ would foster a greater sense of unity and cohesion, attenuating the divide between subsidiary and $\mathrm{HQ}$.

Widening the circle of those engaged in inter-unit knowledge sharing however requires organizational support mechanisms that could go as far as implementing the lingua franca of business, English, as corporate language. Yet whatever corporate language is chosen, the inclusion of non-native speakers might necessitate more focus on language skills at the selection stage of (subsidiary and HQ) managers and greater efforts in terms of language training (Marschan-Piekkari, Welch, \& Welch, 1999b). Further, because much HQ knowledge is transferred to subsidiaries through virtual media, specific considerations have to be taken, for example, with regard to redundant media use, the provision of a media infrastructure and the adoption of new media (Tenzer \& Pudelko, 2014). Additionally, job rotations and other face-to-face interactions in the form of regular meetings, conferences or cross-border projects may not only facilitate knowledge receipt but may also make individuals feel more at ease in cross-language communication and ultimately help them improve their proficiency in the native language of another MNE unit.

While language learning and shared language policies in MNEs are important steps to foster crossunit communication, our results also suggest that by themselves they are unlikely to translate into sufficient organizational benefits, especially in foreign acquisitions. The additional mechanisms that we proposed and tested can further facilitate the transfer of local, contextual knowledge and, by extension, shared social identification. As they are within the control of the organization, the onus is on the MNE to ensure their implementation. One mechanism that is controllable by the MNE involves setting clear goals and a vision for the entire organization that are shared by subsidiary managers. From a social identity perspective, this requires that subsidiary managers, particularly in foreign acquisitions, are able to contribute to the development of MNE strategies and goals, which may be achieved through greater internationalization of an MNE's top management team or the strategic use of inpatriation (e.g., Reiche, 2006). A second mechanism ensuring that shared language leads to knowledge transfer involves centralized HR decisions. Despite the widely assumed benefits of localized HR practices, especially for the subsidiary context, these may be offset by advantages that centralized HR decisions bring for interunit relations in the MNE. HR managers should therefore more explicitly communicate the gains that HR centralization entails.

\section{Limitations and Future Research}

In addition to several strengths, including a large data set across multiple home and host countries, a few limitations have to be noted. A first limitation refers to our use of single respondents per subsidiary and the inherent sources of bias in respondents' perceptions. While this limitation is duly acknowledged, it is 
the result of our large-scale multi-country research design, which made it difficult to obtain data from multiple sources for each subsidiary. Accordingly, we had to make a trade-off between obtaining multisource data and maintaining diversity concerning MNEs' home and host countries to provide a more far-reaching test of the role of shared language. The current study shifted the balance to the latter. Our study compares favorably to extant research in that it draws on primary data and yet has achieved a similar sample size to studies using secondary data $(n=1171$; Boeh \& Beamish, 2012). By comparison, other studies that have also collected primary data tend to have much smaller sample sizes (e.g., $n=105$; Yang et al., 2008). In general, the substantive results of our study do not suggest any particular biases. However, where possible we would encourage future research to collect data from various sources. Implicit to our conceptual arguments is also a level of aggregation that occurs when the social identification of individual knowledge senders and recipients translates into unit-level knowledge flows. While our research design made it unfeasible to collect data on each individual instance of tacit knowledge transfer, we would encourage future studies to more explicitly model these multilevel effects.

A second limitation is the potential of common method bias, which can inflate relationships among variables. We took several measures to minimize this risk, such as separating items for the predictor and criterion variables into different survey sections and using different scale endpoints. In addition, we performed two sets of preliminary analyses in the results section indicating that common method bias is unlikely to be of major concern. Despite these measures, we recognize that common method bias cannot be completely ruled out.

Third, despite the superiority of our newly developed subjective measure of shared language compared with existing country-level measures, we note that our measure does not explicitly include the use of a second language. In our study, second language usage was reflected by the fact that in most cases the second language equaled the official corporate language. However, we would encourage scholars to more explicitly account for second language usage in the future. Similarly, individuals in MNEs may share a common language not only due to their proficiency in another's native language or in the common corporate language but also due to other commonalities such as common industry or technical standards and future research would benefit from considering these additional dimensions. Future research could also develop better objective measures of shared language that address the limitations of currently available country-level measures. For example, scholars could use TOEFL scores and/or language proficiency test scores for languages other than English of each individual manager.

Fourth, while shared language is arguably an important source of social identification, we acknowledge that various other surface-level determinants exist and that these may in fact interrelate. For example, research on biculturals has shown that visual cues of the exchange party's cultural or ethnic origin affect linguistic performance and hence the level of information exchange, despite language commonalities (Zhang, Morris, Cheng, \& Yap, forthcoming). Since our study is not able to examine the interrelationships between various markers of social identification, we would encourage future research to simultaneously account for attributes such as language, ethnicity and gender.

Fifth, while we followed other scholars in operationalizing subsidiary knowledge inflows, we are unable to comment on the extent to which this knowledge is actually used by knowledge recipients. Future work could improve on our study by adopting more direct measures of knowledge exchange, for example, by incorporating assessments of both knowledge senders and recipients in the study design. Similarly, whereas we examined the functional scope of subsidiary knowledge inflows, future studies may also want to explore the perceived functional value of this knowledge. It is also possible that elements of social identity other than language might be more or less salient for the functional scope vs functional value of the knowledge. The importance of shared language, shared HQ goals and vision, and centralization of HR decisions to subsidiary knowledge inflows may also vary with characteristics of knowledge such as relevance, complexity and the level of tacitness. For example, we would assume the motivation to acquire knowledge to increase with perceptions of its relevance. Future research could examine whether these and other characteristics interact with our predictors and affect knowledge receipt.

In sum, over the past few years a growing body of research has studied how knowledge is diffused in MNEs. We contribute to this research stream by expanding the theoretical bases of MNE knowledge flows and conceptualizing shared social identity as an outcome rather than only an antecedent of tacit knowledge flows, which provides an alternative reason for why knowledge flows occur between actors in MNEs. We further show that shared language is an 
insufficient condition for subsidiary knowledge receipt as it also depends on the mediation of organizational mechanisms, especially0 in foreign acquisitions, thereby explaining how language commonalities translate into knowledge flows.

\section{ACKNOWLEDGEMENTS}

The authors would like to thank the three anonymous JIBS reviewers and JIBS area editor Jaeyong Song for their very constructive feedback. We also are grateful to Dana Minbaeva, Helene Tenzer, Sachiko Yamao and Miguel Canela for their valuable and helpful comments on earlier versions of the manuscript. The authors further appreciate the financial support provided by the Spanish

\section{REFERENCES}

Aiken, L. S., \& West, S. G. 1991. Multiple regression: Testing and interpreting interactions. Thousand Oaks, CA: Sage.

Alesina, A., Devleeschauwer, A., Easterly, W., Kurlat, S., \& Wacziarg, R. 2003. Fractionalization. Journal of Economic Growth, 8(2): 155-194.

Arbuckle, J. L., \& Wothke, W. 1999. Amos 4.0 user's guide. Chicago, IL: SmallWaters Corporation.

Argote, I., \& Ingram, P. 2000. Knowledge transfer: A basis for competitive advantage in firms. Organizational Behavior and Human Decision Processes, 82(1): 150-169.

Armstrong, J. S., \& Overton, T. S. 1977. Estimating nonresponse bias in mail surveys. Journal of Marketing Research, 14(3): 396-402.

Ashforth, B. E., Harrison, S. H., \& Corley, K. G. 2008. Identification in organizations: An examination of four fundamental questions. Journal of Management, 34(3): 325-374.

Barner-Rasmussen, W., \& Björkman, I. 2007. Language fluency, socialization and inter-unit relationships in Chinese and Finnish subsidiaries. Management and Organization Review, 3(1): 105-128.

Bhagat, R. S., Kedia, B. L., Harveston, P. D., \& Triandis, H. C. 2002. Cultural variation in the cross-border transfer of organizational knowledge: An integrative framework. Academy of Management Review, 27(2): 204-221.

Birkinshaw, J. M., Hood, N., \& Jonsson, S. 1998. Building firmspecific advantages in multinational corporations: The role of subsidiary initiative. Strategic Management Journal, 19(3): 221-241.

Björkman, I., Stahl, G. K., \& Vaara, E. 2007. Cultural differences and capability transfer in cross-border acquisitions: The mediating roles of capability complementarity, absorptive capacity, and social integration. Journal of International Business Studies, 38(4): 658-672.

Bliese, P. D., \& Hanges, P. J. 2004. Being both too liberal and too conservative: The perils of treating grouped data as though they were independent. Organizational Research Methods, 7(4): 400-417.

Boeh, K. K., \& Beamish, P. W. 2012. Travel time and the liability of distance in foreign direct investment: Location choice and entry mode. Journal of International Business Studies, 43(5): 525-535.

Bouchikhi, H., \& Kimberly, J. R. 2003. Escaping the identity trap. MIT Sloan Management Review, 44(3): 20-26.

Bowen, D. E., \& Ostroff, C. 2004. Understanding HRM-firm performance linkages: The role of the "strength" of the HRM system. Academy of Management Review, 29(2): 203-221.

Brannen, M. Y. 2004. When Mickey loses face: Recontextualization, semantic fit, and the semiotics of foreignness. Academy of Management Review, 29(4): 593-616.

Bucholtz, M., \& Hall, K. 2005. Identity and interaction: A sociocultural linguistic approach. Discourse Studies, 7(4-5): 585-614.
Ministry of Economy and Competitiveness (Project No. MICINN-ECO2012-33544). Part of the research on which this article is based was also supported under Australian Research Council's Discovery Projects funding scheme (project DP0555977). The views expressed herein are those of the authors and are not necessarily those of the Australian Research Council.

\section{NOTE}

${ }^{1}$ An inspection of the variance inflation factors of all independent and moderator variables showed that these were well below the threshold value of 10 (Hair, Black, Babin, Anderson, \& Tatham, 2006).

Buckley, P. J., Carter, M. J., Clegg, J., \& Tan, H. 2005. Language and social knowledge in foreign knowledge transfer to China. International Studies of Management and Organization, 35(1): 47-64.

Cameron, A. C., \& Trivedi, P. K. 2009. Microeconometrics using Stata. College Station, TX: Stata Press.

Chang, Y.-Y., Gong, Y., \& Peng, M. W. 2012. Expatriate knowledge transfer, subsidiary absorptive capacity, and subsidiary performance. Academy of Management Journal, 55(4): 927-948.

Collins, C. J., \& Smith, K. G. 2006. Knowledge exchange and combination: The role of human resource practices in the performance of high-technology firms. Academy of Management Journal, 49(3): 544-560.

Dovidio, J. F., Gaertner, S. L., \& Saguy, T. 2009. Commonality and the complexity of "We": Social attitudes and social change. Personality and Social Psychology Review, 13(1): 3-20.

Dow, D., \& Karunaratna, A. 2006. Developing a multidimensional instrument to measure psychic distance stimuli. Journal of International Business Studies, 37(1): 1-25.

Edwards, J. R., \& Lambert, L. S. 2007. Methods for integrating moderation and mediation: A general analytical framework using moderated path analysis. Psychological Methods, 12(1): $1-22$.

Edwards, T., \& Kuruvilla, S. 2005. International HRM: National business systems, organizational politics and the international division of labour in MNCs. International Journal of Human Resource Management, 16(1): 1-21.

Ellemers, N., de Gilder, D., \& Haslam, S. A. 2004. Motivating individuals and groups at work: A social identity perspective on leadership and group performance. Academy of Management Review, 29(3): 459-478.

Fang, R., Jiang, G.-L.F., Makino, S., \& Beamish, P. W. 2010. Multinational firm knowledge, use of expatriates, and foreign subsidiary performance. Journal of Management Studies, 47(1): 27-54.

Festing, M., Engle, A. D., Dowling, P. J., \& Sahakiants, I. 2012. HRM activities: Pay and rewards. In C. Brewster, \& W. Mayrhofer (Eds), Handbook of research on comparative human resource management: 139-163. Cheltenham: Edward Elgar.

Giles, H., \& Johnson, P. (Eds) 1981. The role of language in ethnic group relations. In, Intergroup behavior: 199-243. Oxford: Blackwell.

Gupta, A. K., \& Govindarajan, V. 2000. Knowledge flows within multinational corporations. Strategic Management Journal, 21(4): 473-496.

Hair, J. F., Black, W. C., Babin, B. J., Anderson, R. E., \& Tatham, R. L. 2006. Multivariate data analysis. Upper Saddle River, NJ: Pearson Prentice Hall.

Harzing, A.-W. 1997. Response rates in international mail surveys: Results of a 22 country study. International Business Review, 6(6): 641-665. 
Harzing, A.-W. 2002. Acquisitions versus greenfield investments: International strategy and management of entry modes. Strategic Management Journal, 23(3): 211-227.

Harzing, A.-W., \& Feely, A. J. 2008. The language barrier and its implications for HQ-subsidiary relationships. Cross Cultural Management: An International Journal, 15(1): 49-61.

Harzing, A.-W., \& Pudelko, M. 2013. Language competencies, policies and practices in multinational corporations: A comprehensive review and comparison of Anglophone, Asian, Continental European and Nordic MNCs. Journal of World Business, 48(1): 87-97.

Harzing, A.-W., \& Pudelko, M. 2014. Hablas vielleicht un peu la mia language? A comprehensive overview of the role of language differences in headquarters-subsidiary communication. International Journal of Human Resource Management, 25(5): 696-717.

Harzing, A.-W. 32 country collaborators. 2005. Does the use of English-language questionnaires in cross-national research obscure national differences? International Journal of CrossCultural Management, 5(2): 213-224.

Heckman, J. 1979. Sample selection bias as a specification error. Econometrica, 47(1): 153-161.

Hennart, J.-F., \& Park, Y.-R. 1993. Greenfield vs. acquisition: The strategy of Japanese investors in the United States. Management Science, 39(9): 1054-1071.

Hinds, P., Liu, L., \& Lyon, J. 2011. Putting the global in global work: An intercultural lens on the practice of cross-national collaboration. Academy of Management Annals, 5(1): 135-188.

Hinds, P. J., \& Mortensen, M. 2005. Understanding conflict in geographically distributed teams: The moderating effects of shared identity, shared context, and spontaneous communication. Organization Science, 16(3): 290-307.

Hogg, M. A., \& Terry, D. J. 2000. Social identity and selfcategorization processes in organizational contexts. Academy of Management Review, 25(1): 121-140.

Kostova, T., \& Roth, K. 2002. Adoption of an organizational practice by subsidiaries of multinational corporations: Institutional and relational effects. Academy of Management Journal, 45(1): 215-233.

Lauring, J. 2008. Rethinking social identity theory in international encounters: Language use as a negotiated object for identity making. International Journal of Cross Cultural Management, 8(3): 343-361.

Li, J. 1995. Foreign entry and survival: Effects of strategic choices on performance in international markets. Strategic Management Journal, 16(5): 333-351.

Lindell, M. K., \& Whitney, D. J. 2001. Accounting for common method bias in cross sectional research designs. Journal of Applied Psychology, 86(1): 114-121.

Luo, Y., \& Shenkar, O. 2006. The multinational corporation as a multilingual community: Language and organization in a global context. Journal of International Business Studies, 37(3): 321-339.

MacKinnon, D. P., Lockwood, C. M., \& Williams, J. 2004. Confidence limits for the indirect effect: Distribution of the product and resampling methods. Multivariate Behavioral Research, 39(1): 99-128.

Mäkelä, K., \& Brewster, C. 2009. Interunit interaction contexts, interpersonal social capital, and the differing levels of knowledge sharing. Human Resource Management, 48(4): 591-613.

Mäkelä, K., Kalla, H. K., \& Piekkari, R. 2007. Interpersonal similarity as a driver of knowledge sharing within multinational corporations. International Business Review, 16(1): 1-22.

Marschan-Piekkari, R., Welch, D., \& Welch, L. 1999a. In the shadow: The impact of language on structure, power and communication in the multinational. International Business Review, 8(4): 421-440.

Marschan-Piekkari, R., Welch, D., \& Welch, L. 1999b. Adopting a common corporate language: IHRM implications. International Journal of Human Resource Management, 10(3): 377-390.

Mehra, A., Kilduff, M., \& Brass, D. J. 1998. At the margins: A distinctiveness approach to the social identity and social networks of underrepresented groups. Academy of Management Journal, 41(4): 441-452.

Michailova, S., \& Mustaffa, Z. 2012. Subsidiary knowledge flows in multinational corporations: Research accomplishments, gaps, and opportunities. Journal of World Business, 47(3): 383-396.

Minbaeva, D. B., Pedersen, T., Björkman, I., Fey, C. F., \& Park, H. J. 2003. MNE knowledge transfer, subsidiary absorptive capacity, and HRM. Journal of International Business Studies, 34(6): 586-599.

Mudambi, R., \& Navarra, P. 2004. Is knowledge power? Knowledge flows, subsidiary power and rent-seeking within MNCs. lournal of International Business Studies, 35(5): 385-406.

Nahapiet, J., \& Ghoshal, S. 1998. Social capital, intellectual capital, and the organizational advantage. Academy of Management Review, 23(2): 242-266.

Neeley, T. 2012. Global business speaks English: Why you need a language strategy now. Harvard Business Review, 90(5): 116-124.

Newburry, W. 2001. MNC interdependence and local embeddedness influences on perceptions of career benefits from global integration. Journal of International Business Studies, 32(3): 497-507.

Noorderhaven, N., \& Harzing, A.-W. 2009. Knowledge-sharing and social interaction within MNEs. Journal of International Business Studies, 40(5): 719-741.

Ochs, E. 1993. Constructing social identity: A language socialization perspective. Research on Language and Social Interaction, 26(3): 287-306.

Orton, J. D., \& Weick, K. E. 1990. Loosely coupled systems: A reconceptualization. Academy of Management Review, 15(2): 203-223.

Peirce, B. N. 1995. Social identity, investment, and language learning. TESOL Quarterly, 29(1): 9-31.

Peltokorpi, V., \& Vaara, E. 2014. Knowledge transfer in multinational corporations: Productive and counterproductive effects of language-sensitive recruitment. Journal of International Business Studies, 45(5): 600-622.

Planken, B. 2005. Managing rapport in lingua franca sales negotiations: A comparison of professional and aspiring negotiators. English for Specific Purposes, 24(4): 381-400.

Podsakoff, P. M., MacKenzie, S. B., Lee, J.-Y., \& Podsakoff, N. P. 2003. Common method biases in behavioral research: A critical review of the literature and recommended remedies. Journal of Applied Psychology, 88(5): 879-903.

Prahalad, C. K., \& Bettis, R. A. 1986. The dominant logic: A new linkage between diversity and performance. Strategic Management Journal, 7(6): 485-501.

Pratt, M. G. 1998. To be or not to be? Central questions in organizational identification. In D. A. Whetten, \& P. C. Godfrey (Eds), Identities in organizations: Building theory through conversations 171-207. Thousand Oaks, CA: Sage.

Pudelko, M., \& Harzing, A.-W. 2007. Country-of-origin, localization, or dominance effect? An empirical investigation of HRM practices in foreign subsidiaries. Human Resource Management, 46(4): 535-559.

Rabe-Hesketh, S., \& Skrondal, A. 2008. Multilevel and longitudinal modeling using Stata, 2nd edn. College Station, TX: Stata Press.

Reade, C. 2003. Going the extra mile: Local managers and global effort. Journal of Managerial Psychology, 18(3): 208-228.

Reiche, B. S. 2006. The inpatriate experience in multinational corporations: An exploratory case study in Germany International Journal of Human Resource Management, 17(9): 1572-1590.

Reiche, B. S. 2007. The effect of international staffing practices on subsidiary staff retention in multinational corporations. International Journal of Human Resource Management, 18(4): 523-536.

Reiche, B. S., Harzing, A.-W., \& Kraimer, M. L. 2009. The role of international assignees' social capital in creating inter-unit intellectual capital: A cross-level model. Journal of International Business Studies, 40(3): 509-526.

Salk, J. E., \& Brannen, M. Y. 2000. National culture, networks, and individual influence in a multinational management team. Academy of Management Journal, 43(2): 191-202. 
Schomaker, M. S., \& Zaheer, S. 2014. The role of language in knowledge transfer to geographically dispersed manufacturing operations. Journal of International Management, 20(1): 55-72.

Schuler, R. S., Budhwar, P., \& Florkowski, G. W. 2002. International human resource management: Review and critique. International Journal of Management Reviews, 4(1): 41-70.

Shenkar, O. 2001. Cultural distance revisited: Towards a more rigorous conceptualization and measurement of cultural differences. Journal of International Business Studies, 32(3): 519-535.

Simonin, B. L. 2004. An empirical investigation of the process of knowledge transfer in international strategic alliances. Journal of International Business Studies, 35(5): 407-427.

Simsek, Z., \& Veiga, J. F. 2001. A primer on internet organizational surveys. Organizational Research Methods, 4(3): 218-235.

Slangen, A. H. L. 2011. A communication-based theory of the choice between greenfield and acquisition entry. Journal of Management Studies, 48(8): 1699-1726.

Song, J. 2014. Subsidiary absorptive capacity and knowledge transfer within multinational corporations. Journal of International Business Studies, 45(1): 73-84.

Stahl, G. K., \& Voigt, A. 2008. Do cultural differences matter in mergers and acquisitions? A tentative model and examination. Organization Science, 19(1): 160-176.

Szulanski, G. 1996. Exploring internal stickiness: Impediments to the transfer of best practice within the firm. Strategic Management Journal, 17(Winter Special Issue): 27-43.

Tajfel, H., \& Turner, J. C. 1979. An integrative theory of intergroup conflict. In W. G. Austin, \& S. Worchel (Eds), The social psychology of intergroup relations: 33-47. Monterey, CA: Brooks/Cole.

Tajfel, H., \& Turner, J. C. 1986. The social identity theory of intergroup behavior. In S. Worchel, \& W. G. Austin (Eds), Psychology of intergroup relations, 2nd edn: 7-24. Chicago: Nelson-Hall.

Tenzer, H., \& Pudelko, M. 2012. The impact of language barriers on shared mental models in multinational teams. Best Paper Proceedings, Academy of Management Annual Meeting, Boston, 3-7 August.

Tenzer, H., \& Pudelko, M. 2014. Selecting communication media in multilingual virtual teams. Paper presented at the Academy of Management Annual Meeting, Philadelphia, 1-5 August.

\section{APPENDIX}

\section{Measure of Shared Language}

1. Is there an official corporate language in the multinational company that this subsidiary is part of?

Response format: (No; Yes, the language of the country of HQ; Yes, other language, please list:

2. How would you assess the following language capabilities?

Response format: $(1=$ very poor to $7=$ native speaker)

(a) Subsidiary managers in the language spoken in the country of HQ.

(b) Subsidiary managers in the official corporate language (as identified above).

(c) HQ managers in the language spoken in the country the focal subsidiary is located in.

(d) HQ managers in the official corporate language (as identified above).
Tsai, W., \& Ghoshal, S. 1998. Social capital and value creation: The role of intrafirm networks. Academy of Management Journal, 41(4): 464-476.

Turner, J. C. 1982. Towards a cognitive redefinition of the social group. In H. Tajfel (Ed), Social identity and intergroup relations 15-40. New York: Cambridge University Press.

Vaara, E., Tienari, J., Piekkari, R., \& Säntti, R. 2005. Language and the circuits of power in a merging MNC. Journal of Management Studies, 42(3): 595-623.

Verbeke, A. 2010. International acquisition success: Social community and dominant logic dimensions. Journal of International Business Studies, 41(1): 38-46.

Vermeulen, F., \& Barkema, H. 2001. Learning through acquisitions. Academy of Management Journal, 44(3): 457-476.

Volk, S., Köhler, T., \& Pudelko, M. 2014. Brain drain: The cognitive neuroscience of foreign language processing in multilingual organizations. Journal of International Business Studies, 45(7): 862-885.

Vora, D., \& Kostova, T. 2007. A model of dual organizational identification in the context of the multinational enterprise. Journal of Organizational Behavior, 28(3): 327-350.

Welch, D. E., \& Welch, L. S. 2008. The importance of language in international knowledge transfer. Management International Review, 48(3): 339-360.

Yamao, S., De Cieri, H., \& Hutchings, K. 2009. Transferring subsidiary knowledge to global headquarters: Subsidiary senior executives' perceptions of the role of HR configurations in the development of knowledge stocks. Human Resource Management, 48(4): 531-554.

Yang, Q., Mudambi, R., \& Meyer, K. E. 2008. Conventional and reverse knowledge flows in multinational corporations. Journal of Management, 34(5): 882-902.

Zhang, S., Morris, M. W., Cheng, C.-Y., \& Yap, A. J. forthcoming. Heritage-culture images disrupt immigrants' second-language processing through triggering first-language interference. Proceedings of the National Academy of Sciences of the United States of America.

\section{ABOUT THE AUTHORS}

B Sebastian Reiche (PhD, University of Melbourne) is an Associate Professor in the Department of Managing People in Organizations at IESE Business School in Barcelona, Spain. His research focuses on international assignments and international HRM, knowledge transfer, employee retention and careers, global leadership and cross-cultural management. He is currently Associate Editor of Human Resource Management Journal and regularly blogs on topics related to expatriation and global work (http://blog. iese.edu/expatriatus).

Anne-Wil Harzing (PhD, University of Bradford) is Professor of International Management at Middlesex University, UK. Her research interests include international HRM, HQ-subsidiary relationships, the role of language in international business, and the quality and impact of academic research. Since 1999 she maintains an extensive website (http://www.harzing.com) with resources for international management and academic publishing. 
Markus Pudelko is Professor of International Business at the University of Tübingen, Germany. He has earned Master degrees in Business Studies (University of Cologne), Economics (Sorbonne University), International Management (Community of European Management Schools) and a $\mathrm{PhD}$ (University of Cologne). His current research is on multinational teams, the impact of language on international business, headquarters-subsidiary relationships and Japanese HRM. (c) (i) $\Theta$ This work is licensed under a Creative Commons Attribution-NonCommercial-NoDerivs 3.0 Unported License. The images or other third party material in this article are included in the article's Creative Commons license, unless indicated otherwise in the credit line; if the material is not included under the Creative Commons license, users will need to obtain permission from the license holder to reproduce the material. To view a copy of this license, visit http://creativecommons. org/licenses/by-nc-nd/3.0/

Accepted by Jaeyong Song, Area Editor, 15 January 2015. This article has been with the authors for three revisions. 